\author{
KAMILA STAŚKO-MAZUR
}

UNIWERSYTET WROCEAWSKI

\title{
SYGNAŁ POLSKIEJ KRONIKI FILMOWEJ I JEGO NIEZNANE WERSJE Z ROKU I967
}

\section{WPROWADZENIE}

W polskim powojennym pejzażu dźwiękowym istniało wiele dominant stanowiących sygnatury miejsca, zdarzenia, stacji, programu radiowego bądź telewizyjnego. Funkcję rozpoznawalnego audytywnie sygnału, obecnego przez dziesięciolecia w pejzażu dźwiękowym kraju za sprawą emisji w kinach miejskich i ruchomych (następnie w telewizji), pełniła także dźwiękowa czołówka zapowiadająca Polską Kronikę Filmową $(\mathrm{PKF})^{\mathrm{I}}$. Sygnał Kronik w pierwszych wydaniach ulegał zmianom, po czym od roku 1952 przez blisko pięćdziesiąt lat funkcjonował w niezmienionej formie, zapowiadając i kończąc tygodnik fanfarą skomponowaną przez Władysława Szpilmana. Historyk PKF, Marek Kosma Cieśliński, stwierdza:

czołówka o charakterystycznym motywie dźwiękowym sygnalizowała początek każdego seansu w każdym kinie w Polsce. Przez pół wieku Kronika była zatem stałym elementem codziennego życia Polaków².

Jak wskazują materiały archiwalne (partytury i nagrania ze zbiorów Wytwórni Filmów Dokumentalnych i Fabularnych, dalej WFDiF)33, oblicze Sygnatu PKF w owym czasie podlegało jednak weryfikacji i bywało restaurowane nie tylko pod względem wykonawczym czy technicznym. Z I967 r. pochodzą projekty kompozycji autorstwa

I Polska Kronika Filmowa emitowana była w 1. I944-94. Jej poprzedniczką była funkcjonująca od I928 r. Kronika Polskiej Agencji Telegraficznej (PAT). Jak zauważają niektórzy badacze tematu, „w praktyce była najatrakcyjniejszą formą kontaktu ze światem. Żadna z gazet nie miała tak licznego grona odbiorców”, zob.: Marek K. Cieśliński, „Polska Kronika Filmowa. Między polityką a sztuką”, w: Chetmska 2I: so lat Wytwórni Filmów Dokumentalnych i Fabularnych w Warszawie, red. Bożena Janicka, Andrzej Kołodyński, Warszawa 2000, s. 30.

2 Marek Kosma Cieśliński, Polska Kronika Filmowa. Podgladanie PRL-u, Olszanica-Warszawa 20I6, s. I4.

3 Zasoby archiwalne warszawskiej Wytwórni Filmów Dokumentalnych i Fabularnych obejmują partytury wraz z głosami (sygn. I2.6) oraz nagranie (sygn. 236). Za pomoc w realizacji kwerendy i w dostępie do źródeł dziękuję pani Teresie Kruczek, redaktor Fonoteki WFDiF. 
czterech kompozytorów - Henryka Mikołaja Góreckiego, Wojciecha Kilara, Władysława Szpilmana oraz Jerzego Maksymiuka - rękopiśmienne autografy, sygnowane bądź podpisane imiennie, które - jak domyślamy się z inskrypcji (np. tytułów) - były wstępnymi propozycjami nowych wersji sygnału, pisanymi dla PKF prawdopodobnie w pierwszym kwartale roku $1967^{4}$. Analizie poddane zostaną autografy partytur wraz z nagraniem z 1967 r. ${ }^{5}$, obejmującym łącznie dziesięć pełnych realizacji kompozycji i towarzyszących im tzw. zakończeń (ostatnie takty sygnałów) oraz cztery wersje nie poddane rejestracji. Nowe projekty dźwiękowej czołówki z roku 1967, nigdy nie wprowadzone do użytku, choć poddane zapisowi akustycznemu, ukazane w kontekście pierwszych wersji sygnału ujawniają różne powstałe wówczas konwencje stylistyczne. Ukazują także losy dźwiękowej oprawy Kroniki autorstwa Władysława Szpilmana uwikłane w skomplikowaną politycznie rzeczywistość PRL.

\section{PIERWOTNE SYGNAŁY POLSKIEJ KRONIKI FILMOWEJ}

\section{Anonimowe sygnały PKF: 1945-5I}

Autorstwo sygnału do pierwszych wydań Kroniki z 1. I945-5I nie zostało dotąd zbadane i określone w literaturze. Informacje o kompozytorach i aranżerach oprawy muzycznej PKF zawarte w materiałach filmowych są nader skąpe ${ }^{6}$, co nie dziwi w kontekście założeń formalnych tego gatunku ; jeśli zdarza się atrybucja, to nierzadko jest nieścisła. Ponadto sam sygnał PKF z tamtego okresu, podobnie jak forma i stylistyka Kroniki, przekształcał się wraz ze zmianami organizacyjnymi i politycznymi, które - jak zauważa Krzysztof Siwoń - pozwolą wypracować dojrzałą stylistykę dopiero około 1949 r., gdy po Jerzym Bossaku, Ludwiku Perskim i Oldze Borzechowej funkcję redaktora przejmuje Helena Lemańska ${ }^{8}$. Analiza audytywna poszczególnych wydań PKF pozwala na atrybucję części utworów stanowiących oprawę dźwię-

4 Jedyną datę dzienną podaje Górecki, opatrując koniec utworu zapisem: „Katowice, 31.03.1967 r.”.

5 Analiza audytywna opiera się na pliku mp3 utworzonym na podstawie oryginalnego zapisu z taśmy WFD Sygnaty do Kroniki / 1967, o sygn. 236; oryginalne pudełko taśmy zawiera opis podający w kolejności nazwiska i czas nagrania oraz informację dotyczącą pierwotnej formy źródła „9 odcinków przedzielonych białymi paskami. Każdy odcinek zawiera sygnał i jego zakończenie. Ostatni odcinek (9) ma dwie wersje tego samego sygnału z zakończeniami”.

6 Nazwiska aranżerów i osób opracowujących muzycznie materiał Kroniki są jeszcze rzadziej wspominane niż autora Sygnatu. Pojawiają się m.in. w krótkich artykułach prasowych, a dopiero od lat sześćdziesiątych umieszczane są w napisach początkowych.

7 O swoistej masowości PKF, transparentności jej twórców i wykluczeniu indywidualizmu - co w sferze kompozycji łączy się także z anonimowością autorów muzyki - wspomina Krzysztof Siwoń, „Muzyka w służbie konwencji. Tygodnik Polskiej Agencji Telegraficznej i Polska Kronika Filmowa lat 1945-1955dwie wariacje na ten sam temat?", Zeszyty Naukowe Towarzystwa Doktorantów UJ, Nauki Humanistyczne 7 (20I3) zesz. 2, s. II4.

8 Por.: K. Siwoń, op. cit. Zapewne nie bez znaczenia były także warunki techniczne - pierwsze odcinki montowano w Lublinie, kolejne w Łodzi, a od roku 1949 Kronika powstawała w całości w Warszawskiej Wytwórni Filmów Fabularnych. 
kową magazynu. W pierwszych dwóch numerach z roku 1945 (opracowanych jeszcze w Łodzi) ścieżka dźwiękowa czołówki „tygodnika filmowego” przypomina marszową pieśń wojskową ze słynnym Hastem Wojska Polskiego (zdecydowano się wybrać cztery ostatnie takty), stanowiąc dźwiękową klamrę jej odcinków, co w warstwie estetycznej uznać można za stylistyczne nawiązanie do PAT-owskiej estetyki.

W kolejnych wydaniach z 1. I945-5I (od odcinka nr 3/45) na otwarcie stosowano jeden i ten sam symfoniczno-fanfarowy motyw kadencyjny. Aranżacja symfoniczna motywu przypomina typowe dla hollywoodzkich produkcji filmowych minionych dekad triumfalistyczne w wyrazie zakończenia fraz finałowych, towarzyszy mu jednocześnie fanfarowy motyw (w partii trąbek) konotujący wojskowo-pompierskie toposy. Stosowany od odcinka 3/45 jako sygnał PKF, funkcjonuje przez około sześć lat i ustępuje miejsca patriotycznym pieśniom (np. Polonezowi Kościuszki) jedynie przy okazji specjalnych, uroczystych odcinków.

Przełom w kwestii dźwiękowego kształtu sygnału następuje wraz z pierwszym numerem Kroniki z I952 r., opatrzonym nowym brzmieniem - skomponowanym specjalnie na jej potrzeby utworem Władysława Szpilmana, funkcjonującym z powodzeniem do ostatnich wydań w 1994 roku. Informacje wskazujące czas powstania kompozycji autorstwa Szpilmana przynoszą wiele rozbieżności w kwestii datacji, a i rękopisy autoryzowanych autografów nie rozstrzygają precyzyjnej daty jego powstania9. Po wojnie Władysław Szpilman stworzył około dziesięciu sygnałów (na rozmaite składy wykonawcze) i na zamówienie kilku instytucji, zrealizowanych w 1. $1948-76^{10}$. Jedynym jak dotąd (odautorskim) źródłem wskazującym właściwą datę powstania sygnału PKF jest wypowiedź zarejestrowana podczas wywiadu z kompozytorem przeprowadzonego w 1985 r. przez Jolantę Górniewicz ${ }^{\mathrm{II}}$. Dowiadujemy się z niej nie tylko o czasie powstania kompozycji, ale i o konkretnych założeniach odnośnie do formy i stylistyki planowanej kompozycji. Powołane w lipcu i945 r. Państwowe Przedsiębiorstwo Filmowe, utworzone w miejsce Czołówki Filmowej Wojska Polskiego, któremu podlegały zarówno Kronika Filmowa, jak i produkcje

9 Najwcześniejszą datę powołania Sygnatu autorstwa Władysława Szpilmana wprowadza monografia WFDiF w Warszawie, podając rok 1947 jako czas, w którym „Polska Kronika Filmowa otrzymuje własny sygnał muzyczny skomponowany przez Władysława Szpilmana”. Nie wiadomo jednak, jaki Sygnat mają na myśli autorzy. Marek Kosma Cieśliński, badacz Polskiej Kroniki Filmowej, w najnowszej publikacji (op. cit., s. 8) wskazuje, że „Sygnał dźwiękowy - od roku 1949 autorstwa kompozytora i pianisty Władysława Szpilmana - staje się nieodłącznym znakiem rozpoczynającego się seansu kinowego", przesuwając datę powstania Szpilmanowskiego Sygnatu o dwa lata. W innej publikacji (Piękniej niż w życiu. Polska Kronika Filmowa 1944-1994, Warszawa 2006, s. 70) ten sam autor łączy rok 195I z okresem, w którym pojawia się „nowy [...] sygnał dźwiękowy, skomponowany przez Władysława Szpilmana, nieco później również nowa czołówka”.

IO Rekonstrukcja odnalezionych przez autorkę utworów sygnałowych zawarta jest w pracy doktorskiej analizującej twórczości kompozytora, przygotowanej w Instytucie Muzykologii Uniwersytetu Wrocławskiego.

II Jolanta Górniewicz, $Z$ wizytą u Wtadystawa Szpilmana, Polskie Radio 1985, Archiwum Polskiego Radia, sygn. $15677 /$ I. 
filmów dokumentalnych ${ }^{12}$, dokonało zamówienia sygnału jeszcze w I95I roku. Idea formy sygnału - przekazana przez Stefana Jarocińskiego ${ }^{\mathrm{I3}}$ - była klarownie zarysowana: miał posiadać „polskie brzmienie, rytm poloneza i charakter fanfar” ${ }^{14}$. Zgodnie ze słowami kompozytora powstały wówczas trzy wersje utworu. Efekt realizacji został dogłębnie przeanalizowany przez Macieja Gołąba w szerokim kulturalno-społecznym ujęciu ${ }^{15}$. Kontynuując wywołany wątek proponuję prezentację kompozycji w świetle jej nowych źródeł i w kontekście powstałych w 1967 r. nieznanych dotąd projektów sygnałowych.

\section{Władysława Szpilmana Sygnat Polskiej Kroniki Filmowej (1951/52)}

Pierwszy rękopiśmienny autograf Sygnatu pochodzi ze zbiorów WFDiF i obejmuje dwie niemal tożsame wersje utworu: Sygnat I w tonacji B-dur i II Sygnat do Kroniki-w $C$-dur. Skład wykonawczy obejmuje w obu przypadkach ten sam zespół: grupę instrumentów dętych - trąbki (I, II), rogi w F ( I, II) i puzony (I, II), kwintet smyczkowy oraz kotły. Akustyczne realizacje utworu zarejestrowane są w tonacji $B$-dur, obejmują więc wersję partytury oznaczonej jako Sygnat I, która stanowić będzie podstawę analizy.

Sygnat wyróżnia synteza kilku współistniejących formotwórczych elementów, zakomponowanych w wyjątkowo przemyślną formułę podnoszącą napięcie przez nieoczekiwaną modulację ${ }^{16}$, chwilowo jedynie unoszącą hejnałową melodię, by zaraz powrócić do wyjściowej tonacji i jej czołowego motywu sygnałowego, stanowiącego triumfalne rozwiązanie uroczystego w wyrazie quasi-symfonicznego przebiegu.

Formę - w zapisie dziesięciotaktową, w metrum trójmiarowym - podzielić można np. ze względu na przebieg morfologicznych jednostek na trzy części lub ze względu na przeprowadzenia frazy hejnałowej na dwie (po pięć taktów) - przy czym w ramach pierwszej z nich, po trzech taktach ukazujących czoło i jednocześnie hejnałowy motyw sygnału (pierwszy formotwórczy element), należy wskazać

I2 Formalnie pod nazwą Przedsiębiorstwo Państwowe „Film Polski” działa do I I I952 r., kiedy obowiązki przedsiębiorstwa przejmuje Centralny Urząd Kinematografii, por.: „Kalendarium”, opr. Mariusz Miodek, w: Chetmska 2I, op. cit., s. IO-I2. Szerzej na temat skomplikowanej sytuacji prawnej „Filmu Polskiego” por.: „Tylko fakty”, opr. Jadwiga Głowa, w: Chetmska 2I, op. cit., s. 22-29.

I3 Stefan Jarociński w 1. I947-52 był konsultantem muzycznym Polskiego Radia. Jak wskazuje Dariusz Michalski, Jarociński współpracował także z Przedsiębiorstwem Państwowym „Film Polski”, którego częścią była Wytwórnia Filmów Dokumentalnych, zob.: Dariusz Michalski, Piosenka przypomni ci... czyli historia polskiej muzyki rozrywkowej (lata 1945-1958), Warszawa 2010, s. I9.

I4 O postaci Stefana Jarocińskiego, który przekazał konkretne wytyczne stylistyczne planowanej kompozycji, wspomina poza Władysławem Szpilmanem także Dariusz Michalski w telewizyjnym magazynie Leksykon polskiej muzyki, 1990 r., prezentując archiwalne zapisy filmowe z kompozytorem grającym Sygnat na fortepianie - oraz w publikacji Piosenka przypomni ci..., op. cit., s. 219.

I5 Maciej Gołąb, „Władysława Szpilmana sygnał czołówki Polskiej Kroniki Filmowej (I95I)”, Kwartalnik filmowy 39 (2017) nr 97-98, s. 278-293.

I6 Szczegółowej analizy harmonicznej Sygnału PKF (wraz z ilustracją oryginalnej karty partytury) dokonuje Maciej Gołąb (op. cit.). 
umiejscowienie wspomnianej modulacji, przenoszącej melodykę ku pierwszej kulminacji w wysokim rejestrze ( $D$-dur) i jej descendentalny odwrót. Szósty takt przynosi powrót do tonacji $B$-dur i jednocześnie kontynuację wyjściowej, sygnałowej motywiki (rytmicznie przywołując początkowy motyw, w warstwie melodycznej postępującej sekundowo), sukcesywnie zmierzającej ku kadencji i końcowej tonice (t. 6). Jest ona podkreślona przez ujawnioną w pełnej krasie figurę rytmiczną w akompaniujących smyczkach, która dopowiada charakter à la polonaise utworu (kolejny formotwórczy element). Polonezowy motyw rytmiczny uzupełnia fakturę prowadzonego w blasze tematu także i we wcześniejszych taktach (I, 4, 5, 6), lecz w dyskretnej, jedynie zamarkowanej grupie rytmicznej ósemki (czasem ominiętej, jak w t. I) i dwóch szesnastek oraz następującej po niej długiej wartości, realizowanej przez smyczki i kotły. Zarówno otwierająca kompozycję mazurowa figura rytmiczna melodii, jak i akompaniujące polonezowe rytmy w smyczkach i kotłach, stanowią rozdrobnione odmiany rytmicznej formuły ionicus a minore - wyszczególnionych przez Karola Hławiczkę w ramach polonezowych jednostek typowych dla chorea polonica ${ }^{\mathrm{I}}$.

Kolejna, szkicowa wersja partytury, odnaleziona w zbiorach archiwalnych ZAiKS w formie partycji fortepianowej, nie wyszczególnia tych drobniejszych polonezowych rytmów, które wypełniają główną narrację t. I-6; ukazuje zarazem najistotniejsze elementy kompozycji: zarys melodyczno-harmoniczny formy wraz z czołową grupą melodyczną i finałową rytmiczną grupą polonezową (realizowaną akustycznie przez kwintet smyczkowy détaché). Zapis tego autografu różni się ponadto od pełnoobsadowego rękopisu z WFDiF kierunkiem melodii drugiego taktu. Na słabe części taktu prezentuje ich odbicie lustrzane względem oryginału, co jest szczegółem nie bez znaczenia (zob. il. I).

Otwierające kompozycję takty (t. I-3), zwłaszcza w powyższym zapisie (z partycji fortepianowej), wykazują zbieżność z prozodią i kierunkiem melodyki początkowych taktów hymnu Polski. Kontur rytmiczny Mazurka Dąbrowskiego (w swej ugruntowanej dwudziestowiecznej formie) nawiązuje również do archetypicznej figury ionicus minor, łączącej pierwotne formuły „rytmów polskich” ${ }^{18}$.

Krótka forma utworu jest więc pojemna w konotacje, łącząc cechy idiomu hejnałowego, zaznaczonego figurą melodyczną w pierwszym takcie (nawiązanie do hejnałowej formuły triady), z symbolicznymi elementami polskiej choreotechniki obecnymi w rytmicznych ukształtowaniach utworów o charakterze patriotycznym.

I7 Por:: Ewa Dahlig-Turek, „Rytmy polskie” w muzyce XVI-XIX wieku. Studium morfologiczne, Warszawa 2006.

I8 Ibid., s. 39 . 


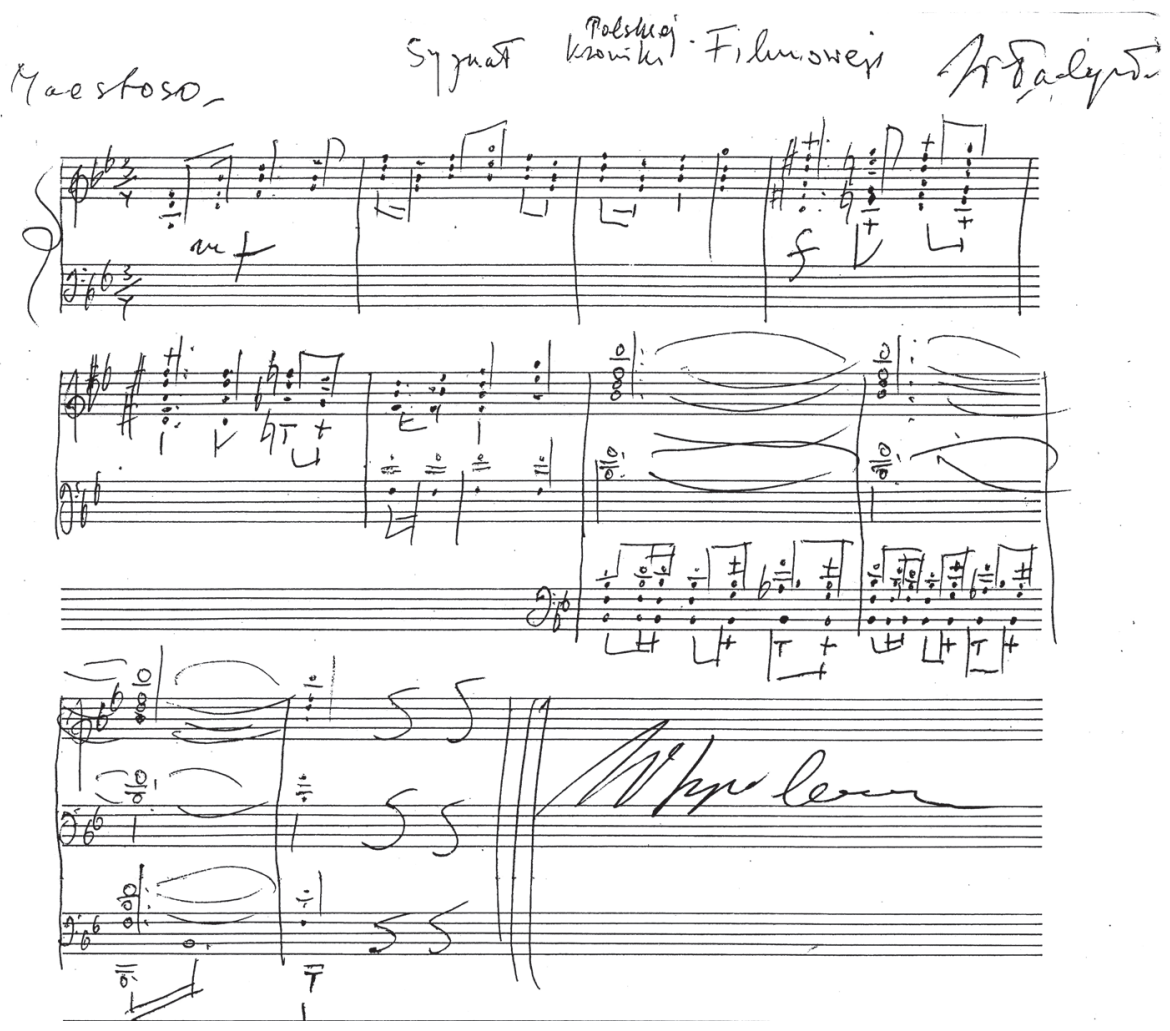

Il. I. Rękopis fortepianowej partycji Sygnatu Polskiej Kroniki Filmowej Władysława Szpilmana. Archiwum ZAiKS.

3. Realizacja akustyczna Sygnatu PKF Władysława Szpilmana: 195I-67

W fonograficznych źródłach Archiwum WFDiF funkcjonują dwa pierwotne zapisy Sygnatu Szpilmana: pierwszy pochodzący z I95I r. ${ }^{19}$ oraz drugi nagrany w $1967 \mathrm{rr}^{20}$. Zasadniczą różnicą między pierwszą realizacją akustyczną i tą pochodzącą z roku 1967 jest jakość techniczna nagrania, związana z nowymi możliwościami zarówno zapisu, jak i postprodukcji oraz - jak można mniemać - z akustyką wybranej sali nagraniowej.

Podstawową różnicą dwóch realizacji (odsłuchanych w autoryzowanej wersji mp3 z WFDiF) jest ich profil panoramiczny. Nagranie z 195I r. odzwierciedla w gruncie rzeczy monofoniczną ścieżkę dźwiękową. Stereofonia Sygnatu PKF jest w tym wypadku pozorna poprzez zdublowanie tej samej - czyli identycznej - ścieżki w kanale

I) Nagranie Sygnatu początkowego (otwierającego Kronikę) oraz Sygnatu końcowego (stanowiącego wariantową wersję nagrania, stworzoną na potrzeby kadrów zamykających magazyn).

20 Analogiczne nagranie Sygnatu i Zakończenia pochodzące z taśmy o sygn. 236: WFD Sygnaty do Kroniki/ I967. 
prawym i lewym. Sygnat nie ma więc ani głębi, ani tych wszystkich walorów sonicznych, które stanowią o dobrym (dziś typowym), pełnym pod względem wszystkich zakresów i zróżnicowania obwiedni, obliczu stereofonicznego obrazu akustycznego. Mankamentem nagrania poza spłaszczonym brzmieniem jest wyraźny klik przypadający na pierwszy impuls utworu, który stanowi swoistą sygnaturę otwarcia nagrania z I95I roku. Mimo wspomnianych niedomogów związanych z technologią realizacji, anonimowe wykonanie utworu z 195I r. można ocenić pozytywnie. Zarówno dynamiczny profil całego przebiegu (jak się domyślamy, nie wynikający z ingerencji realizatora akustycznego, lecz z konsekwencji wykonawców i dyrygenta), jak i intonacja, precyzja artykulacyjna pozostają wierne partyturze i na poziomie odpowiadającym domniemanym ówczesnym możliwościom realizującego zespołu. Tempo po pierwszej kulminacji (t. 3) ulega drobnej retardacji, lecz tuż przed ostatnim crescendem (t. 9) dogania metronomiczny puls $(J=97)$. Zakończenie zarejestrowane jest w znacznie żywszym tempie $(\downarrow=\mathrm{I} 2 \mathrm{O})$, z poprawnym zachowaniem wszystkich wykonawczych cech obecnych w partyturze.

Inaczej przedstawia się sytuacja realizacji akustycznej z 1967 roku. Specyficzną cechą stereofonicznego już wówczas zapisu jest obecność pogłosu. Rejestracja dokonana prawdopodobnie w dużej sali (bądź z dodaniem sztucznego pogłosu) tworzy iluzję nagrania wyjątkowego - o szerokiej panoramie, a tym samym uroczystym charakterze. Precyzja realizacji jest oczywiście bez porównania z pierwotną wersją. W rzeczywistości jednak nowa wersja wydaje się być mniej dynamiczna i klarowna od znacznie gorzej nagranej/zagranej wersji pierwotnej z I95I roku. Głównym mankamentem pozornej przestrzenności nagrania z 1967 r. jest niewielka asynchroniczność między kanałami prawym i lewym, wprowadzająca rozchwianie rytmicznej precyzji utworu oraz wykluczająca selektywność głosów (szczególnie instrumentów dętych blaszanych). Kwestie wykonania także nie wydają się przynosić korzyść nowej wersji Sygnatu, wręcz przeciwnie, jakby odwracały autorskie intencje artykulacyjnodynamiczne w kilku istotnych detalach ${ }^{21}$. Puls przebiega podobnie jak w wersji z I95I r. - spowalniając w momencie modulacji do wyższej tonacji, osiąga wyjściowe tempo dosłownie na ostatnią nutę taktu Io. Odstępstwem od tak wykonanego Sygnatu jest zapis obejmujący Zakończenie. Zagrane z większym przekonaniem i odpowiedną crescendową dynamiką, jest jednak wykonane w wolniejszym tempie $(J=89)$, tracąc przy tym impet fanfarowo-finałowego charakteru. Także i w tym nagraniu nie są znani wykonawcy ${ }^{22}$, którzy choć realizują partyturę zgodnie z zapisem (przynajmniej

2I Trąbki, mimo iż operują w granicy fortissimo, momentami jakby celowo forsowały dźwięk. W dynamice przebiegu podkreślono pozorną, a nie właściwą (ostatnią) kulminacją utworu: w finale zamiast zrealizowania fortissimo w siódmym takcie, kluczowy moment utworu wykonany jest płasko, a ostateczne crescendo przypadające na dziewiąty takt zagrane jest nieco bezsilnie.

22 Sposób wykonania sugeruje jednak, że oba wykonania mogły być dokonane pod dyrekcją tego samego dyrygenta. 
co do wysokości nut), to jednak jakby wbrew końcowej energetyce formy. Nowa wersja (I967) nie znalazła więc zastosowania w kolejnych wydaniach Kroniki, ustępując miejsca nagraniu z I95I r. (funkcjonującym do roku 1970).

W pierwotnym zapisie akustycznym (z I95I r.) warto zauważyć jeszcze dwa szczegóły wykonawcze. Pierwszy dotyczy realizacji tzw. Sygnatu początkowego ${ }^{23}$, który w jednym miejscu odbiega od zapisu znanego z partytur przechowywanych w archiwach WFDiF. W szóstym takcie jeden z wykonawców grupy instrumentów dętych blaszanych gra partię obejmującą grupę rytmiczną złożoną z synkopy i czterech ósemek, a nie jak na kartach autografu synkopy i dwóch ćwierćnut. Tym samym rytmiczna grupa polonezowego akompaniamentu w smyczkach (wprowadzona właśnie w tym takcie) zostaje wzmocniona tubalnym głosem w blasze dublującym swoisty rytm nazwany przez Karola Hławiczkę „instrumentalnym”, najbardziej typową figurą akompaniującą poloneza ${ }^{24}$. Czy ta drobna, ale - ze względu na techniczną odsłonę nagrania z lat pięćdziesiątych, niezbyt fortunnie operującego planami - szczególnie dobrze słyszalna niesubordynacja była osobistą inwencją muzyka realizującego partię, czy wręcz przeciwnie - oddawała zapis trzeciego wariantu (wspomnianego przez kompozytora w wywiadzie), nieznanej wersji kompozycji? Być może łączy obie możliwości, bądź stanowi pozytywną odpowiedź i jednocześnie rozwiązanie drugiego szczegółu realizacyjnego - zagadki związanej z rodzajem tonacji czołówki Kroniki. Analiza brzmieniowego komponentu wybranych wydań tygodnika dostępnych w bazach archiwalnych (w formie audiowizualnej: Filmoteka Narodowa, Ninateka, YouTube) wykazuje, że kadry otwierające magazyn w pierwszych latach wydania rozbrzmiewały w różnych tonacjach (nie licząc prezentacji rozchwianych tonalnie): zbliżonej do $H$-dur (do połowy lat sześćdziesiątych), w $C$-dur (około nr 36A/65), zaś po dokonaniu kolejnego nagrania w $1970 \mathrm{r}^{25} \mathrm{w}$ tonacji $B$-dur. Półtonowe różnice pomiędzy tonacjami mogły być determinowane technologicznymi wymogami (prędkość odtwarzania taśmy lub jej przeznaczenie), które stanowiły klucz do stworzenia tożsamego co do materii muzycznej II Sygnatu do kroniki w tonacji C-dur oraz hipotetycznej trzeciej wersji w $H$-dur, prawdopodobnie zawierającej wskazany wyżej ósemkowy motyw w szóstym takcie jednego z instrumentów blaszanych.

\section{PROJEKT NOWEGO SYGNAEU PKF W ROKU I967}

Stereofoniczna realizacja sygnału z 1967 r. nie obejmuje jednak jedynie kompozycji Władysława Szpilmana ( $B$-dur), lecz także i nowo powstałe kompozycje sygnałowe wspomnianych wyżej autorów. Nie zachowały się szczegółowe źródła przybliżają-

23 Źródłowe nagranie obejmuje trzy wersje: Sygnat początkowy, środkowy, końcowy. Ich realizacje związane były z funkcjami, jakie pełnić miały w poszczególnych fazach Kroniki (początkowej, wewnętrznej i końcowej).

24 Por.: E. Dahlig-Turek, op. cit., s. 48.

25 Nagranie z I970 r. szerzej analizuje Maciej Gołąb (op. cit.). 
ce kontekst i inspirację owego przedsięwzięcia. Wiadomo natomiast, że dokonują się wówczas pewne zawirowania wokół wciąż negocjowanego kształtu PKF. Wraz z odcinkiem nr 36B (odcinki B przeznaczone były tylko dla kin miejskich ${ }^{26}$ ) z sierpnia I967 r. wprowadzono nową planszę czołówki autorstwa plastyka Wojciecha Zamecznika. Nowa czołówka nie zdążyła jednak zaistnieć długo, bowiem - jak dowiadujemy się z nr. 46A/67 (listopad) - szybko nastąpił „na skutek interwencji widzów PKF powrót starej planszy”. Możemy domyślać się, że działania ingerujące w wizerunek otwierających kadrów Kroniki mogły mieć związek także z nagraniem nowych muzycznych wersji sygnału. Ale być może istniały także i inne, polityczne przesłanki inicjujące zmiany personalne oraz inspirujące powstanie nowych form czołówki. Łukasz Jędrzejski zauważa:

Rok 1967 przyniósł zmianę na stanowisku redaktora naczelnego PKF. W wyniku wybuchu wojny sześciodniowej w PKF przygotowano materiał na temat agresji Izraela. Tekst do tego wydania przygotowali Karol Małcużyński oraz Jerzy Kasprzycki. Helena Lemańska odmówiła udziału w rozpoczynającej się kampanii antysyjonistycznej. W dotyczącej jej notatce Służby Bezpieczeństwa nadmieniono: „Tekst ten Lemańska próbowała złagodzić, lecz Główny Urząd Kontroli Prasy, Publikacji i Widowisk go odrzucił i wniósł poprawki. Z tego powodu Lemańska była w dużej rozterce, że potępiono Izrael jako agresora przez kierownictwo partii i rząd PRL” (Instytut Pamięci Narodowej, Notatka dotycząca Heleny Lemańskiej, IPN/BU-oI224I682). Warto również odnieść się do wspomnień Lemańskiej z opisywanego okresu: „W toku wojny sześciodniowej władze domagały się antyizraelskiego, antysemickiego stanowiska kroniki, oraz języka w niej używanego. Odmówiłam udziału w zaczynającej się kampanii antyizraelskiej, czytaj antysemickiej. Dymisję złożyłam na ręce ministra Zaorskiego. To nie był jeszcze paroksyzm antysemityzmu roku 1968. W wytwórni nie chciano robić szumu. Formalnie przeniesiono mnie do działu dokumentu ${ }^{27}$.

Czy konkurs na nowy sygnał miał bezpośredni związek z antysemickimi gestami władz, zawirowaniami personalnymi, a nowe kompozycje miały zająć miejsce dotychczasowego utworu? Czy może zostały stworzone w ramach mniej lub bardziej oficjalnego konkursu i projektowanych przemian wizerunku czołówki - tego nie wiemy ${ }^{28}$. Możemy jednak prześledzić ich charakter i brzmienie za sprawą zachowanych źródeł.

26 Joanna Orzel, „Polska Kronika Filmowa - dokument z dziejów propagandy”, w: Stowo, obraz, dżwięk w edukacji historycznej, red. Stanisław Roszak, Małgorzata Strzelecka, Agnieszka Wieczorek, Toruń 2oro, s. $72-77$, zob. s. 75 .

27 Łukasz Jędrzejski, „Polska Kronika Filmowa w latach 1945-I968 jako medium partyjne. Zarys problemu”, Polityka i Spoteczeństwo I4 (2017) nr I, s. I58-I70. Dodajmy, że Helena Lemańska na stanowisku redaktora pracowała do sierpnia 1967 r. (Chetmska 2I, op. cit., s. 25) lub, jak podają inne źródła, do czerwca.

28 W znanych mi źródłach biograficznych kompozytorów omawianych sygnałów brak informacji na temat przedsięwzięcia. Jerzy Maksymiuk potwierdził autentyczność rękopisu partytury, choć zarówno kompozycje, jak i samo zamówienie nie zachowały się w jego pamięci. 
Nagranie wraz z partyturami zdają się tworzyć spójny komplet źródeł zaświadczający o istnieniu procedury konkursowej. Karty rękopisu (z WFDiF) sygnału autorstwa Władysława Szpilmana oznaczone są w dwójnasób. Rewers dwustronicowej karty nut Sygnatu I Szpilmana posiada dopisany czarnym długopisem adres kompozytora, pod którym mieszkał on w latach sześćdziesiątych, nuty zaś opatrzono cyfrą 3 (I Sygnat) i za (II Sygnat do Kroniki). Dopiski sugerują, iż dawny rękopis (pochodzący najprawdopodobniej z końca I95I r.) został w latach sześćdziesiątych ponownie skierowany do realizacji akustycznej (i domniemanej konkursowej). Także strony tytułowe wybranych nowych sygnałowych partytur z $1967 \mathrm{r}$. opatrzone są podobną dopisaną numeracją (duża cyfra arabska „w kole”, czarnym tuszem), świadczącą o rodzaju kwalifikacji. Nagranie pochodzące z 1967 r. obejmuje, oprócz kompozycji Szpilmana, projekty autorstwa Henryka Mikołaja Góreckiego, Wojciecha Kilara i Jerzego Maksymiuka i prezentuje wybrane utwory w kolejności niemal całkowicie pokrywającej się z dopisaną na partyturach numeracją ${ }^{29} \mathrm{w}$ następującym układzie:

I. W. Kilar (o'I7"+ o'os")

2. H.M. Górecki (o'16" + o'os")

3. W. Szpilman (o'16"+ o'04")

4. J. Maksymiuk I (o'I6"+ o'o6")

5. J. Maksymiuk 2 (o'16" + o'06")

6. J. Maksymiuk 3 (o'15" + o'os")

7. J. Maksymiuk 4 (o'18" + o'o5")

8. W. Kilar wersja bez smyczków (o'I6"+ o'o5")

9. H.M. Górecki wersja bez smyczków (o'15"+ o'o6"; o'15" + o’05")

Dodajmy, że wspomniane nagranie nie wyczerpuje wszystkich zgłoszonych do konkursu propozycji; partyturowe źródła wykazują bowiem kilka dodatkowych wersji sygnału autorstwa Jerzego Maksymiuka, które nie zostały poddane realizacji akustycznej, uwzględnione jednak zostaną w poniższej analizie.

\section{Wojciecha Kilara Sygnat P.K.F (projekt) [symbol I]}

Utwór Wojciecha Kilara został opatrzony numerem i i nagrany na taśmie jako pierwszy. Jak domyślamy się z cyfr dopisanych czarnym tuszem na środku strony tytułowej partytury, przewidziano aż cztery wersje kompozycji: w tonacji $E$-dur, F-dur, w E-dur bez smyczków i w F-dur bez smyczków. Partytura ze zbiorów WFDiF prezentuje sygnał rozpoczęty w tonacji $E$-dur, rozpisany wraz z partią smyczków (dwie karty). Stanowi ona podstawę realizacji akustycznej dla dwóch wersji nagrania - ze

29 Wyjątkiem w zbieżności numeracji, której poddane zostały rękopisy, i kolejności nagrań jest realizacja szóstego nagrania na taśmie, którym jest Wersja VIII Maksymiuka o nadanym numerze 8. Tymczasem numerem 6 opatrzono polonezową Wersję nr III Maksymiuka, której nie nagrano na taśmę. 
smyczkami i bez. Kolejna karta prezentuje dwa ostatnie takty osobno rozpisanego Zakończenia, wykazujące drobne różnice względem oryginału ${ }^{30}$.

Utwór pomyślany jest ze swoistym rozmachem i jednocześnie aluzją stylizacji. Bogaty skład instrumentalny obejmuje sześćdziesięciu wykonawców orkiestry symfonicznej ${ }^{3 \mathrm{I}}$. Opatrzony jest wskazaniem agogiczno-wykonawczym Maestoso i w wybranych taktach marcattissimo, stąd jego charakter waha się między uroczystym i jednocześnie ozdobno-sygnałowym. Brzmieniowo łączy elementy tonalności rozszerzonej z elementami neoklasycznymi i archaizacji (szerokie konotacje m.in. religijne). Obejmuje łącznie sześć taktów, z ósemkową wartością przedłużającą wybrzmiewanie utworu na siódmy takt (w metrum trójmiarowym), co w efekcie daje nieco ponad Is sekund muzyki.

Postęp energetyczny utworu odczytać można jako wyjątkowo szybko osiąający swą kulminację: tuż za uroczystą introdukcją (t. 2-3) w formie serii kilku miarowych pionów współbrzmień, konotujących fakturę tradycyjnych pieśni religijnych (motyw psalmodyczny). Następujący później motyw melodyczny (zdynamizowany użyciem synkopowej formuły rytmicznej - wyraźnie podgonionej w realizacji akustycznej) jest jego rozwinięciem, kolejne frazy zaś jakby topofonicznym echem w wariancie instrumentacji prowadzącym do eufonicznego zamknięcia w kadencji zawieszonej. Forma łączy elementy kształtowania typowe dla utworów uroczystych (o znamionach chwalebnej pieśni) z formułami konotującymi toposy sygnałowe (pojedyncze użycie synkopowo-galopującego motywu w t. 4): grupa instrumentów blaszanych pełni przewodnią rolę, zaś kotły - fanfarowe wypełnienie rytmiczne (dodatkowo podkreślone w wybranych fragmentach użyciem krótkiej, sygnałowej artykulacji), typowe także dla najpopularniejszej wśród późniejszych sygnałowych kompozycji Wojciecha Kilara, sygnału Dziennika telewizyjnego ${ }^{32}$.

Wykonanie ukazuje przede wszystkim różnice wynikające z użycia pełnej i niepełnej obsady. Nagranie bez smyczków wypada mniej korzystnie, choćby w taktach ukazujących topofoniczne echo motywu melodycznego, pozbawionego dywanowego brzmienia, uwypuklającego niekorzystne intonacje blachy. Delikatne różnice tempa odczuwalne są w wersji ze smyczkami intensywniej realizując pochiss. Allarg. zalecone w końcowych taktach; wahania obejmują także znacznie ożywiony synkopowany (w blasze) takt 4 (w obu wersjach). Podobnie jak w analizowanym nagraniu Szpilmana, także i tu obecne jest delikatne przesunięcie w panoramie, powodujące szybsze wybrzmiewanie lewego kanału względem prawego, nie dające jednak tak asynchro-

30 Różni je układ głosów w kontrafagotach i kontrabasach oraz poszerzenie składu o partie dzwonów i talerzy. Mimo klasycznej obsady i neoklasycystycznej brzmieniowości kompozytor stosuje znaki przynutowe, oznaczenie tempa podaje dwojako: „d = $80(\mathrm{I}$ takt $=2,5)$ ”.

3 I Fl. picc., Fl., Ob., Cl. picc. (Es), Cl. (B), Fg., Cfg., 4 Cor. (F) , 4 Tr. (C), 3 Tbm., 1 Tb., 3 Batt.: Pt., Cmp., Timp., Pf., 18 Vn. (I, II), 6 Vle, 6 Vc., 6 Cb. (IV-VI: pięciostrunowe).

32 Wojciech Kilar jest ponadto autorem kilku innych kompozycji sygnałowych rzadko wykazywanych w spisach dorobku. 
3 Maestoso, tutti \&f, $=80\left(1\right.$ takt $\left.=2,5^{\prime \prime}\right)-$
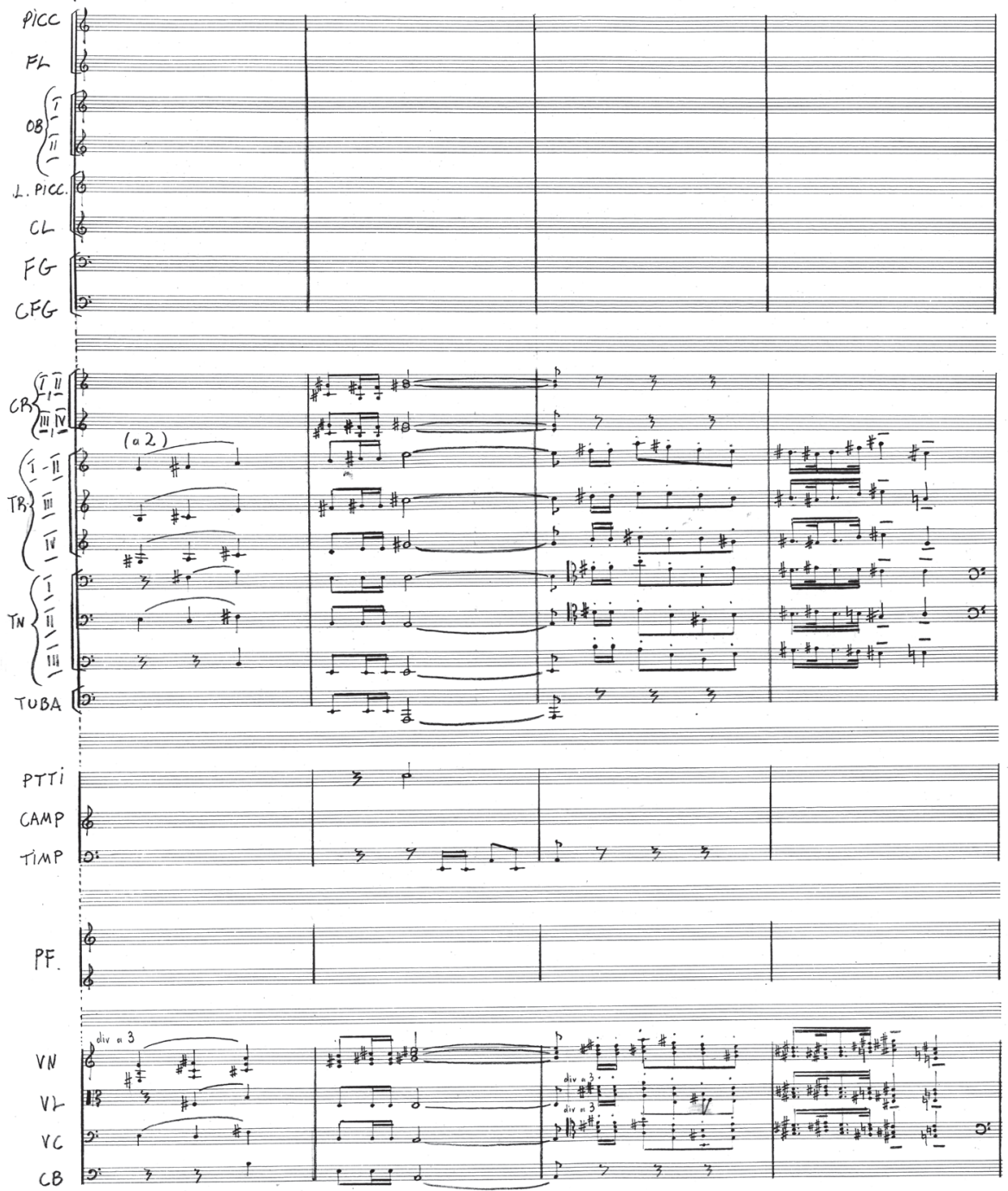

Il. 2. Pierwsza strona Sygnatu P.K.F. Wojciecha Kilara (1967 r.). Zbiory archiwalne WFDiF. 
nicznego wrażenia, oraz nieco dobitniejsze (ale tylko niewiele wolniejsze od pełnego nagrania) wykonanie Zakończenia (nagranego tym razem w pełni synchronicznie lub wręcz z odwrotnym usytuowaniem mikrofonów).

2. Henryka Mikołaja Góreckiego Sygnat do Polskiej Kroniki Filmowej na instrumenty dęte [symbol 2, 2a]

Utwór Henryka Mikołaja Góreckiego - zgodnie z podpisem na karcie tytułowej określony jest jako Sygnat do Polskiej Kroniki Filmowej na instrumenty dęte. Tytułowy skład - 2 flety, 4 klarnety, 2 fagoty, 2 kontrafagoty, 4 rogi, 4 trąbki, 4 puzony, I tuba - w partyturze uzupełniony jest swoistą doklejką obejmującą partię kwintetu smyczkowego zaznaczoną jako archi - ad libitum ${ }^{33}$ oraz kartą z rozpisanym Zakończeniem (stanowiącym w istocie kopię oryginalnego zapisu uzupełnionego o partię rogów).

Czternastotaktowy sygnał oparty jest na ciekawym pomyśle konsekwentnie realizowanym na zasadzie kumulacyjnego przyrostu brzmienia, który, syntetyzując, opisać można jako szereg wznoszących się w górę krokami kwartowymi współbrzmień sekundowych, oraz na rozwiązaniu repetowanego sześciodźwięku powstałego na skutek utrzymania kwartowych składników szerokiego współbrzmienia na pion akordu C ${ }^{4,9}$ (bez tercji; t. 9-IO) i zwrot kadencyjny w formie następujących po sobie i przesuwanych paralelnie akordów $\mathrm{C}^{6}-\mathrm{B}^{4,7} \mathrm{C}$, zamykających wywoławczo-sygnałowe zawołanie (t. II-I4).

Rozbudowujące się współbrzmienie wypełniają w warstwie horyzontalnej triolowe motywy (przypadające na każdy takt w formie ozdobnikowej34). Każdorazowo pierwszy dźwięk trioli stanowi jednocześnie składnik kwartowego (bądź kadencyjnego - w II fazie) współbrzmienia przypadającego na mocne części taktu w grupie instrumentów dętych drewnianych i wzmocniony jest w dwóch innych grupach instrumentów (blacha, smyczki) długo wybrzmiewającymi wartościami. Kwartowa brzmieniowość fazy kumulacyjnej i konsekwentne poszerzanie brzmienia stanowią oś funkcji sygnałowo-fanfarowej, zamkniętej eufonicznym brzmieniem (o charakterze quasi-gloryfikacyjnym, zob. il. 3).

Nagranie uwzględnia wykonanie w pełnej obsadzie wraz z partią smyczków ${ }^{35}$ oraz dwie wersje bez kwintetu smyczkowego. Realizacja akustyczna postępuje niespiesznie w pełnej obsadzie $(d=66)$ i jest znacznie żywsza w wersji bez archi $(d=76)$, utrzymując zalecany poziom dynamiczny $(f f)$ i agogiczny. Jedynym odstępstwem realizacji

33 Partytura obejmuje łącznie trzy karty wraz ze stroną tytułową oraz dodatkową kartę z wyciągiem. Wersja partytury uwzględniająca partię instrumentów smyczkowych została najprawdopodobniej stworzona przez kompilację oryginalnej karty partytury z kartą obejmującą partię archi.

34 Podstawowy dźwięk, jego wychylenie sekundowe w górę i powrót na dźwięk wyjściowy. Odstępstwem od tej reguły są wybrane współbrzmienia m.in. końcowej kadencji, w których triolowe wychylenia następują w kierunku opadającym 7-6-7.

35 Smyczki dublują materiał harmoniczny instrumentów dętych drewnianych w pierwszej fazie w układach ósemkowych, w drugiej fazie z zachowaniem tej samej rytmiki. 


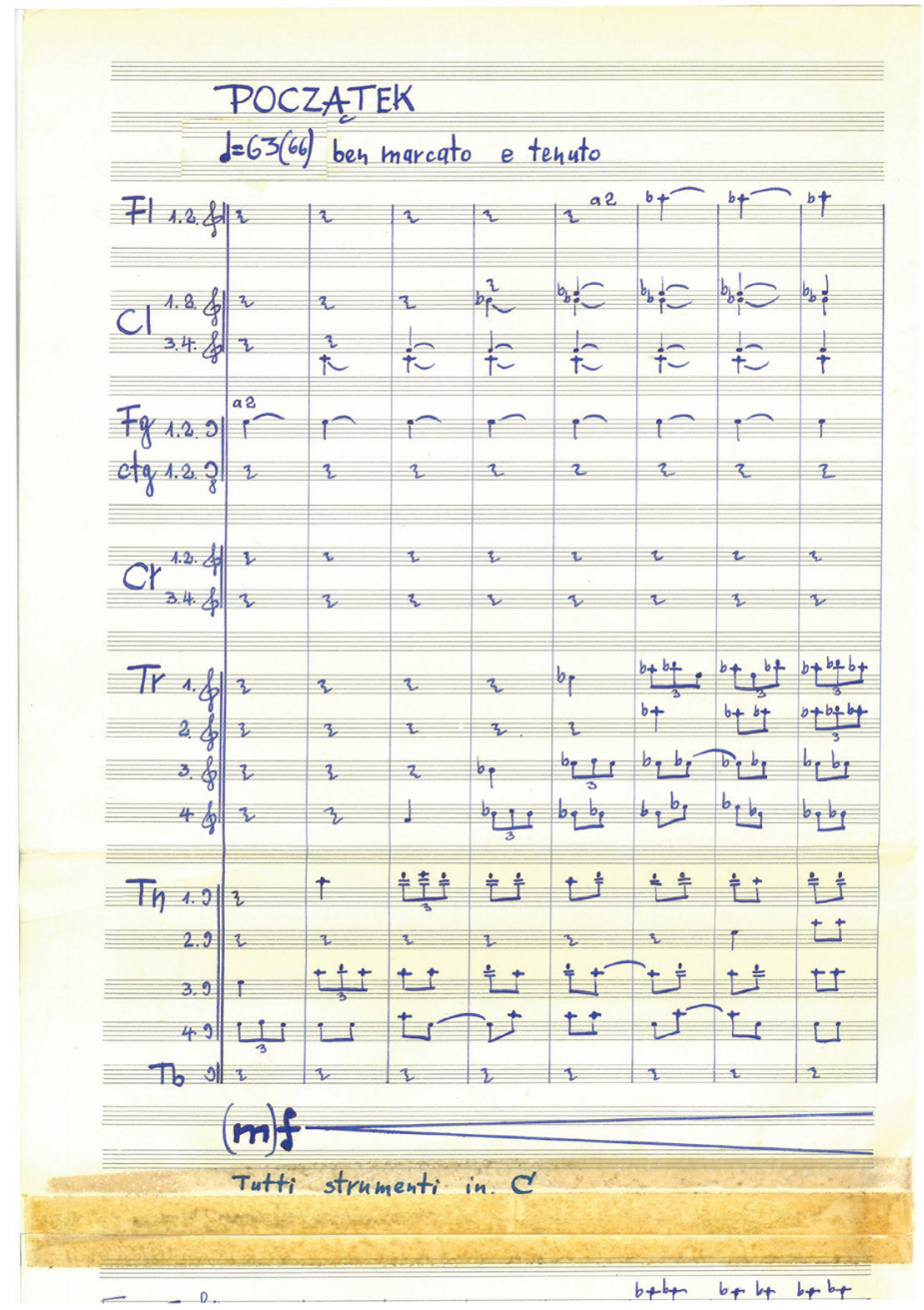

Il. 3. Pierwsza strona Sygnatu na instrumenty dęte Henryka Mikołaja Góreckiego (3I III I967 r.) [bez archi]. Zbiory archiwalne WFDiF.

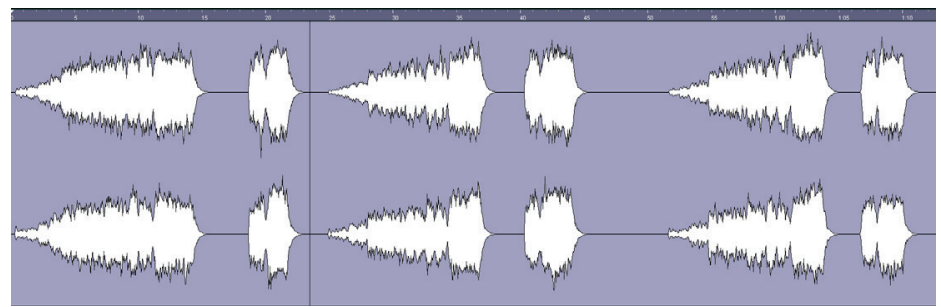

Il. 4. Sonogram nagrania trzech wersji Sygnatu do Polskiej Kroniki Filmowej na instrumenty dęte Henryka Mikołaja Góreckiego (1967). Od lewej: wersja w pełnej obsadzie, kolejne wersje bez kwintetu smyczkowego. 
(w obu wersjach nagrania) od zapisu partyturowego jest zamiana partii w głosach t. 9 i Io, w których ósemkowe triole tercjowe słychać m.in. w instrumentach dętych drewnianych, a nie w trąbkach, jak ma to miejsce w zapisie rękopisu. Pierwsze z dwóch nagrań wersji bez archi wydaje się być znacznie lepsze od drugiego, które zbyt ostro uwypukla partie instrumentów dętych blaszanych - co widoczne jest na sonogramie w postaci wyraźniejszych pików. Ilustracja dobrze obrazuje także proporcje i amplitudy brzmienia różne w dwóch obsadach oraz czasy trwania nieco wolniej wykonanych Zakończeń we wszystkich trzech wersjach nagrania (zob. il. 4).

Ze względu na obsadę wykonawczą, lapidarną formę i swoiście zawoalowany element repetycji - w formie stabilnych układów rytmicznych - Sygnat do Polskiej Kroniki Filmowej w dorobku kompozytorskim Góreckiego usytuować można obok Wratislaviae gloria - sygnału Festiwalu Polskiej Muzyki Współczesnej we Wrocławiu, z końca I968 roku. Wyrazowo jest jednak skrajnie różny od archaizującej i jednocześnie pełnej niepokojącego patosu quasi-chorałowej kompozycji dedykowanej Andrzejowi Markowskiemu.

\section{Jerzego Maksymiuka propozycje sygnału do Polskiej Kroniki Filmowej}

Partytury autorstwa Jerzego Maksymiuka obejmują łącznie dziesięć wersji sygnału podpisanych przez kompozytora jako: $I, I I, I I I, I V, V, V I, V I$ bis, VII, VII bis, VIII ${ }^{36}$, zaś realizacja akustyczna obejmuje wybrane cztery propozycje (których nadpisana numeracja nie pokrywa się z rzymską odautorską). Wersje I, II oraz IV (nieopatrzone numeracją arabska) nie zostały nagrane na taśmę, zaś Wersja III posiada cyfrę świadczącą o kwalifikacji, lecz nie funkcjonuje w źródłowym nagraniu. Kolejność analizowanych utworów nastąpi zgodnie z układem nagrań na taśmie; następnie omówione zostaną cztery ciekawe kompozycje niepoddane realizacji akustycznej.

\section{I. Jerzego Maksymiuka wersje sygnału poddane realizacji akustycznej} Wersja VII [symbol 4$]^{37}$

Czwarta w kolei na źródłowym nagraniu (następująca za kompozycją Szpilmana), a oznaczona przez kompozytora jako siódma (VII) wersja sygnału, ma charakter uroczystej, eklektycznej fanfarowej wywoławczej introdukcji na pełen skład sym-

36 Rozpisane ołówkiem na pewuemowskim czterostronicowym papierze zajmują Io stron numerowanych (I-II - brak strony szóstej), lokując każdą wersję na osobnej stronie; sygnowane „J.M.”. Całość rękopisów ujęta jest w obwolutę z szarej tektury zatytułowaną: „Sygnaty do Kroniki J. Maksymiuk”; podano skład pulpitów w instrumentach smyczkowych: „Archi zawsze Vn I 9/Vn II 9/ Vle 6/ Vc 6/ Cb 6” oraz układ poszczególnych wersji: czerwoną kredką od dołu „I/IV/II/----/VI bis/VII/---/III/VIII/V/VI/ VII bis”. Wyszczególniono składy (u dołu lub u góry strony) i adnotacje wykonawcze (niebieskim długopisem), tempo oraz czas trwania - Is" (czerwoną kredka).

37 Partytura podpisana jako Wersja VII bis, oznakowana jako nr 4, czwarty w kolejności plik dźwiękowy po sygnałach Kilara, Góreckiego i Szpilmana. 
foniczny ${ }^{38}$. W zamyśle formalnym wykorzystuje - podobnie jak kompozycje Góreckiego - zasadę kumulacji napięcia dominantowo-tonicznego poprzez repetycję synkopowo-ósemkowego motywu. Eksponuje w pierwszej fazie energię dźwiękową stopniowo budowanej i niejako zawieszonej dominanty nonowej, która w drugiej fazie zostaje w pełnym brzmieniu dwukrotnie powtórzona i rozwiązana na tonikę F-dur. Dystynktywną cechą ośmiotaktowego sygnału jest ostinato rytmiczne: synkopa (ósemkowa), ćwierćnuta, pauza ósemkowa, trzy ósemki ${ }^{39}$.

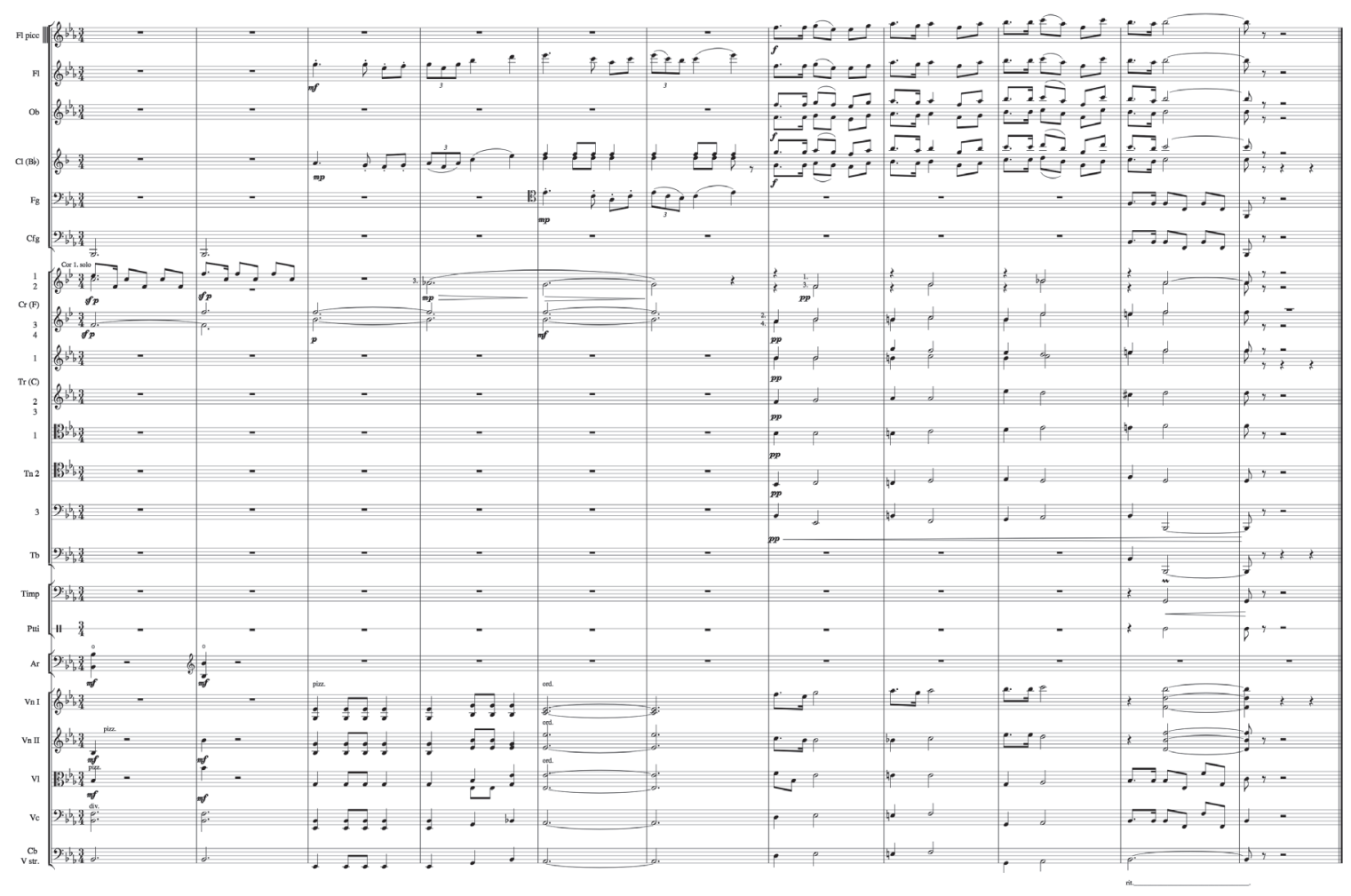

Przykł. I. Projekt Sygnatu do Kroniki Jerzego Maksymiuka, Wersja VII bis (1967). Opracowanie własne na podstawie materiałów archiwalnych WFDiF.

38 Obsada obejmuje: Fl. picc., 2 Fl., 2 Ob., 2 Cl. (B), 2 Fg., I CFg., 4 Cor. (F), 4 Tr. (C), 3 Trb., Tb., 3 Batt. Timp., Tamb., Piatto, Archi: 9 Vni I , 9 Vni II, 6 Vle, 6 Vc., 6 Cb.

39 Początkowo rytmiczny motyw prezentuje pojawiające się kolejno w instrumentach dętych blaszanych (repetowane w obrębie motywu) dysonujące we współbrzmieniach kwartowo-sekundowych składniki dominanty nonowej $\left(\mathrm{D}^{4,6,7}\right)$; w t. 3-4 komórka rytmiczna ostinata ulega redukcji do czołowej synkopy z ćwierćnutą, zacieśniając czy symbolicznie przyspieszając narrację. W drugiej fazie (t. 5, 6) pełne współbrzmienie zawieszonej dominanty powtórzone jest dwukrotnie na mocną część taktu w geście utrzymania napięcia dążącego do rozwiązania, które następuje w ostatnim takcie, wybrzmiewając na tle typowo fanfarowych dopowiedzeń w kotłach. 
Konsekwentne powtarzanie sygnałowego motywu rytmicznego oraz kumulacyjny charakter wstępny - rozbudowywanego brzmienia dominanty - w wyrazowej warstwie jest nawiązaniem do idiomu fanfarowego i formuł marszowych użytych m.in. w pierwszych taktach Marsza weselnego z Suity „Sen nocy letniej” Felixa Mendelssohna-Bartholdy'ego, wykorzystujących podobną zasadę repetycji motywu.

Wersja VII jest pierwotna, Wersja VII bis stanowi jej uzupełnienie i podstawę nagrania. Różnice dotyczą zasadniczo instrumentacji 5-7 taktu, który w wersji pierwotnej pozbawiony jest partii fletów na drugą i trzecią miarę (t. 5-6) na rzecz ósemkowego motywu w blasze ${ }^{40}$. Obie różną się ponadto opracowaniem t. 5-6 w partii instrumentów smyczkowych ${ }^{41}$. Nagranie pełnej wersji wydaje się być zrealizowane wykonawczo i akustycznie bez zarzutów. Z kolei Zakończenie - zagrane znacznie wolniej - traci na wartości oraz ponownie wykazuje nieznaczną różnicę w synchronizacji kanału lewego i prawego, co skutkuje efektem echa.

\section{Wersja $\operatorname{nr} V[\text { symbol } 5]^{42}$}

Wersja $n r V$ to ośmiotaktowa kompozycja w metrum parzystym, oznaczona jako Con Marcia, przeznaczona na skład symfoniczny ${ }^{43}$. Symetrycznie ukształtowana forma ogranicza zróżnicowanie fakturalno-melodyczne do kilku podstawowych funkcji triady repetowanych w pionach akordowych (w układach tercjowych) i urozmaiconych rozdrobnieniami rytmicznymi na zakończeniach fraz ${ }^{44}$; stanowi aluzję do utworów o reprezentacyjnym charakterze, inaugurujących uroczystości dworskie (ewentualnie, przy zmianie trybu i braku rozdrobnień rytmicznych, ceremonie funeralne). Charakter uroczystej kompozycji marszowej zapewnia poza rytmiką faktura homofoniczna sprowadzona do użycia sugestywnych następstw konsonujących współbrzmień, instrumentacja z bogatą grupą instrumentów dętych blaszanych oraz perkusją podkreślającą mocne części taktu. Użyta w sygnale tonacja $A$-dur wraz z klasycznymi ciążeniami podstawowych funkcji, których następstwo sprzężone jest z symetryczną budową, tworzy typową formę poprzednikowo-następnikową ${ }^{45}$.

40

Wersja VII zawiera jednak adnotację uwzględniającą alternatywne wykonanie z dodatkowym motywem w klarnetach. Pomysł klarnetowego motywu został rozwinięty w wersji VII bis do pełnego opracowania motywu w partii instrumentów dętych drewnianych.

4

Instrumenty smyczkowe w omawianym fragmencie w pierwotnej wersji „wzmacniają” synkopowy motyw tematyczny, w wersji bis akcentują jedynie mocne części taktu.

42 Wersja autorska oznaczona jako numer V; partytura oznakowana cyfrą arabską 5, piąty w kolejności plik dźwiękowy po sygnałach Kilara, Góreckiego i Szpilmana i zarazem drugi spośród czterech nagranych sygnałów autorstwa Maksymiuka obecny na źródłowej taśmie WFDiF.

43 Obsada obejmuje: Fl. picc., 2 Fl., 2 Ob., 2 Cl. (B), 2 Fg., Cfg., 4 Cor. (F), 4 Tr. (C), 5 Tbn., 1 Tb., 1 Tmb., Timp. (A, E, D), Tmb. s.c., Ptti, 9 Vn. I, 9 Vn. II, 6 Vle, 6 Vc., 6 Cb.

44 Drobniejsze wartości rytmiczne stanowią jednocześnie urozmaicenie harmoniczno-fakturalne.

45 Poprzednik (t. I-4) zsyntetyzować można do formy T-S, następnik zaś (t. 5-8) uogólnić jako T-D ${ }^{4}$ - tonikalizowany w fis poprzez modulację diatoniczną i zakończony I stopniem z tercją pikardyjską, akordem Fis. 
Akustyczna wersja zrealizowana jest bez większych zarzutów. Pogłos nie wydaje się dominujący, nagranie nie wykazuje asynchronii między kanałami, utrzymane jest $\mathrm{w}$ równym pulsie (część główna $J=63$, Zakończenie $J=52$ ) i stabilnej dynamice; realizuje zapis z użyciem drugiej wolty (a więc kończy utwór kadencją zwodniczą) i prawdopodobnie bez partii tamburyna.

Wersja VIII [symbol 8] $]^{46}$

VIII wersja sygnału (umieszczona na taśmie jako szósta z kolei), o obsadzie symfonicznej bez kwintetu smyczkowego ${ }^{47}$, ze względu na metrorytmiczny charakter (grupowanie ósemkowe) wykazuje związki z kompozycjami realizującymi topos polowania ${ }^{48}$. Możemy także wskazać nawiązanie do elementów gigue w wersji włoskiej (giga) z charakterystycznym niesynkopowanym rytmem, metrum wyjściowym I2/8 i frazami podkreślającymi czteromiarowy podział taktu (z główną miarą obejmującą ćwierćnutę z kropka) ${ }^{49}$ oraz paraleli do cacci.

Forma utworu budowana jest na zasadzie progresyjnego przenoszenia (i wariantowania) podstawowego motywu tematu w coraz wyższe tonacje za sprawą dwóch modulacji oraz uroczystego zakończenia kadencją w $B$-dur (relacje mediantowe). Formotwórczy dwutaktowy zwrot melodyczno-rytmiczny ukazany w coraz wyższych rejestrach blachy ulega swoistej komprymacji czasowej. W pełnej formie zaprezentowany jest w tonacji $F$-dur (t. I-2), następnie w zredukowanej do taktu formie (pozbawionej repetycji motywów cząstkowych) w tonacji $A$ (t. 3), ostatecznie w wariancie zredukowanej formy w tonacji $F$ is (czasowo identyczna komprymacja graficznie ujęta na półtora taktu 4-5), zakończony dwoma pionami akordowymi (S, T) kadencji w B-dur.

Instrumentacja - wykorzystująca zasadniczo grupę dętych blaszanych - przekształca taneczny potencjał kompozycji w kierunku fanfarowym, ugruntowanym przez metrorytmiczne elementy toposu polowania. Wersja akustyczna, ponownie wykazuje nieznaczną asynchroniczność między kanałami prawym i lewym. Stąd mimo wykonania utrzymującego puls $(\mathrm{J}=96$; Zakończenie $\mathrm{d}=86)$, towarzyszy mu efekt pogłosowy.

Wersja $n r$ VI i VI bis [symbol 7 $]^{50}$

Wersja nr VI umieszczona na nagraniu jako siódma z kolei, jest jedyną pośród kompozycji sygnałowych Maksymiuka przeznaczoną wyłącznie na obsadę instrumentów

46 Wersja VIII; partytura oznakowana cyfrą arabską 8, szósty w kolejności plik dźwiękowy na taśmie po sygnałach Kilara, Góreckiego, Szpilmana i dwóch Maksymiuka. Nadanie tej wersji numeru 8 rozbija (jednorazowo) zbieżność chronologii numeracji arabskiej względem kolejności nagań.

47 Fl. picc., 2 Fl., 2 Ob., 2 Cl. (B), 2 Fg., Cfg., 4 Cor., 4 Tr., 3 Tbn., 1 Tb., 3 Batt: Timp., Tmb., Ptti.

48 Por.: Raymond Monelle, The sens of music: Semiotic essays, Princeton 2000, s. 39.

49 Podobnie jak pozostałe wersje utworów Maksymiuka kompozycja nie ma wyszczególnionego metrum, opatrzona jest oznaczeniem wskazującym liczbę głównych miar w takcie.

50 Partytura podpisana jako Wersja VI oznakowana cyfrą arabską 7 (siódmy w kolejności plik dźwiękowy po sygnałach Kilara, Góreckiego i Szpilmana i zarazem czwarty spośród czterech nagannych sygnałów autorstwa Maksymiuka; Wersja VI bis, oznaczona jako 7a). 
dętych blaszanych i perkusję w składzie: 4 trąbki $(C), 4$ rogi $(F), 3$ puzony, tuba, 5 kottów $(D, A, C i s, C, F)$, tamburyn, talerze. Parzyste, marszowe metrum (4/4) sprzyja symetrycznej budowie, zorganizowanej wokół dwutaktowego motywu przewodniego realizowanego zasadniczo w partii trąbek i uzupełnionego charakterystycznym rytmem w kotłach (motywu, dodajmy, użytego w innej konwencji w Wersji nr VII):

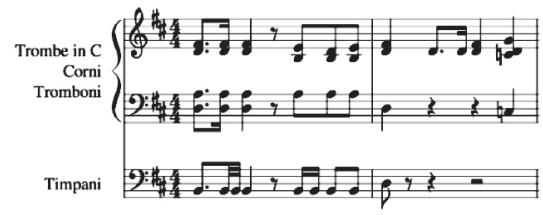

Przykł. 2. Jerzy Maksymiuk, Wersja nr VI, motyw przewodni.

Podstawowy motyw ukazany jest najpierw w tonacji $D$-dur (t. I-2), następnie podjęty w progresji w tonacji $F$-dur (t. $3-4$ ) i w $A$-dur w jednotaktowym wariancie rytmicznym powtórzonym dwukrotnie (t. 5-6), zakończony figurą rytmiczną wykorzystującą grupę ćwierćnuty i synkopy, zamkniętą zawieszonym współbrzmieniem górnej medianty. Forma budowana jest więc na zasadzie progresyjnego ukazywania głównego motywu w coraz wyższych rejestrach $(D-F-A-C i s)$, zgodne z częstą zasadą fanfarowego „podniesienia” 5 i repetycji motywu czołowego.

Wersja VI bis różni się nieznacznie od Wersji VI: skład instrumentalny pozbawiony jest tamburynu, głosy zamienione są w partiach poszczególnych instrumentów. Nagranie realizuje wersję partytury, w której nie występuje tamburyn. W wykonaniu zwraca uwagę mocne wyeksponowanie crescendowej dynamiki ostatniego taktu oraz brak środkowego motywu w partii kotłów. Ograniczenie motywiki tego instrumentu do pierwszego i ostatniego taktu sprawia wrażenie niepełnej narracji fakturalnej. Zakończenie wykonane nieco wolniej wykazuje znacznie bardziej przekonujący profil dynamiczny.

3.2. Jerzego Maksymiuka propozycje sygnału nie poddane realizacji akustycznej Wersja I, Wersja II [brak symbolu]

Dwie wersje utworów podpisane przez kompozytora jako $I$ i $I I$ utrzymane są w sonorystycznej aurze brzmieniowej i zapisane z użyciem współczesnej grafiki. Wersja I przeznaczona jest na pełną obsadę symfoniczną z fortepianem ${ }^{52}$. Regulacja czasu

5I O różnych strategiach formotwórczych - w tym o wspomnianym „unoszeniu” motywów w tradycji muzyków i repertuaru ludowego instrumentów sygnałowych - pisze m.in. Piotr Dahlig, Muzyka adwentu, Warszawa 2003.

523 Fl. picc., 3 Ob., 3 Cl. (Es), Cfg., 4 Cor. (F), 4 Tr. con sordino, 4 Tbn., Pf., Tmb., Ptto. picc., Ptto. medio, Ptto. grande, Timp., 1-12 Vn. I, 1-12 Vn. II, 1-10 Vle, 1-8 Vc., 1-6 Cb. 
i tempa określona jest przez minutaż (wskazujący czas trwania jednego taktu: $d=$ 60) i szkicowo zaznaczonych ram taktów w poszczególnych grupach instrumentów.

Ciekawy fakturalnie sygnał operuje kontrastującymi fakturami - chmurami „punktowych” bądź dywanowych współbrzmień, z użyciem klasterów i układów operujących komórkami brzmień wykorzystujących niewielkie, „krążące” interwały i „kroki trytonowe” w specyficznej instrumentacji ${ }^{53}$. Wersja I ma aurę brzmieniową nawiązującą do ilustracji muzycznej o niepokojącej symbolice; formę w pierwszej fazie o ruchliwym charakterze (być może dalekie echo historycznych konotacji sygnałowych rozpoznanych przez Heyde'a oraz Waltera jako improwizowany grupowo bruityzm ${ }^{54}$ ), w drugiej fazie (t. 9-15) - od wejścia fortepianu - o wyraźnym kierunku kinetycznym zmierzającym do teatralnego rozwiązania energii w quasi-tonalnym ${ }^{55}$ następstwie pionów i zakończonego à la fanfarowym budowaniem kulminacji w kwartowym nawarstwieniu współbrzmień w blasze (t. IO-I2).

Wersję II o podobnej obsadzie ${ }^{56}$ charakteryzuje zbliżony pomysł formalny: operujący podobnym zestawem klasterów ukazanych w coraz wyższych rejestrach, rozdysponowany jednak z wykorzystaniem punktowanej rytmiki i prostszej, asocjacyjno-tonalnej motywiki quasi-melodycznej57. Alternatywą partytury jest wariantowa wersja uzupełniona o melodyczny motyw tercjowo-kwartowy ukazany na tle początkowego dywanowego klasteru (t. 2-3) w formie pasażowego motywu realizowanego przez partię fortepianu, kontrafagotu i kwintetu smyczkowego (wariant partytury zaznaczony jest w didaskaliach). Użycie tego motywu obok następujących w dalszej części (dialogujących) buduje narrację o funkcjach ilustracyjnych, z elementami nawiązującymi do tradycyjnej formuły sygnałowej, poprzez zastosowanie zarówno punktowanej rytmiki introdukcji (t. I-2), użycie motywu synkopy (t. 5-6), jak i przedzielającego je motywu melodycznego, będącego wariantem typowych triadowo-sygnałowych pasaży hejnałowych.

Oscylowanie sekundowe ukazano w kolejnych rejestrach instrumentów smyczkowych, dętych drewnianych, dętych blaszanych. Perkusyjne motywy urozmaicone są przez zastosowanie nieregularnego sforzato i staccato oraz klasterów w rogach con sordino. Gestem ukierunkowującym obsesyjnie pulsującą narrację jest prezentacja - najpierw w partii fortepianu i kontrabasu - krótkich, „wspinających się" pasaży sekundowo-kwartowych, następnie dłuższych kwartowych współbrzmień - w blasze - budujących kadencję wspartą przez grupę instrumentów smyczkowych, a zakończoną krótkim klasterem w wysokim rejestrze instrumentów drewnianych i akcentem perkusji.

54 Por.: Edward H. Tarr, „Fanfare”, w: NGD, New York ${ }^{2} 200 I$, t. 8, s. 543-544.

55 Dla potrzeb analizy można odnotować w Sygnale rodzaj centralizacji tonalnej związanej z użyciem określonych ambitusów klasterowych.

562 Fl. picc., 2 Cl. (B), Cfg., 6 Cor. (F), 7 Tr. (C), 4 Tmb., 1 Tb., Pf., Batt: Tmb. s.c, Timp., Ptto. medio, Frusta, 1-36 (ossia 1-24) Vn. I, 1-10 (ossia 1-8) Vle, 1-8 (ossia 1-6), Vc., 1-6 (ossia 1-6) Cb

57 Klaster rozpoczynający sygnał (instrumenty blaszane, środkowy rejestr: $f^{\mathrm{I}}-a s^{\mathrm{I}}$ ) budowany jest stopniowo z użyciem rytmu punktowanego (t. 3-4); ukazane po nim kolejne klastery w wysokim rejestrze (w repetowanych synkopowanych pionach: $h^{\mathrm{I}}-d e e^{2}, e^{2}-g^{2}$ ), dialogują z krótkimi (ósemki), wspinającymi się w „kwartowych krokach” dźwiękami w smyczkach, zakończone zaś są utrzymaną w manierze dialogu wymianą klasterów w blasze i pionów w smyczkach (ćwierćnuty), które rozwiązują się na finalne współbrzmienie tutti. Ostatnie trzy takty tworzą swoistą quasi-kadencję. 


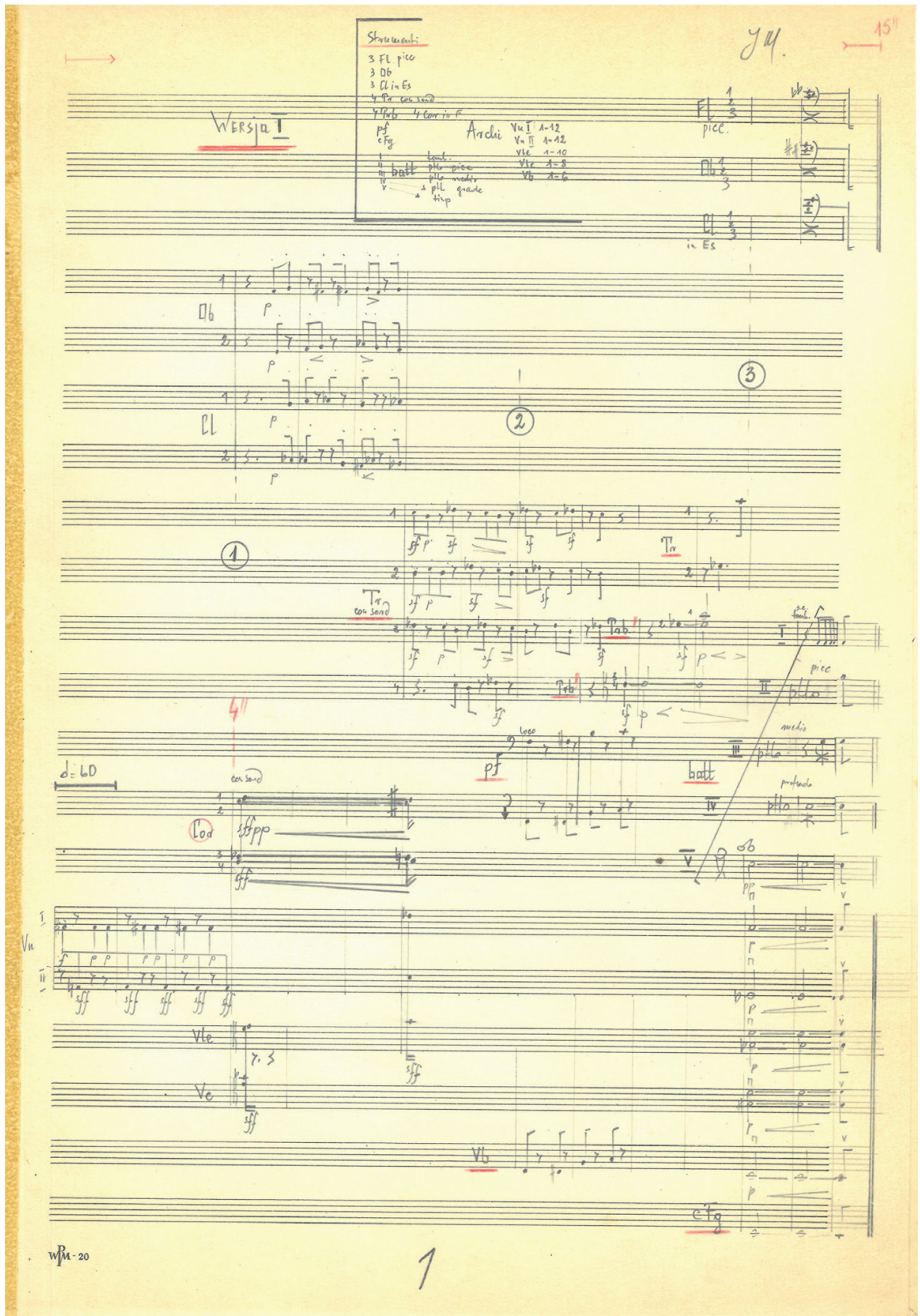

Il. 5. Propozycja Sygnatu do Kroniki Jerzego Maksymiuka, Wersja I (1967).

Zbiory archiwalne WFDiF. 
Zarówno Wersja I, jak i Wersja II stanowią jednak - poprzez swój brzmieniowo-fakturalny charakter - zaprzeczenie dotychczas stosowanej tonalno-klasycyzującej formuły sygnałowej Kroniki PAT czy PKF. Na tle pozostałych wersji wyróżniają się zdecydowanie pod względem barwowym, formalnym i estetycznym. Stanowić mogą intencjonalnie indywidualną - a więc i rozpoznawalną - propozycję planowanego sygnału, bądź celowo wywrotową realizację w formie sarkastycznego komentarza.

Wersja IV [brak symbolu]

Wersja IV podobnie jak dwie poprzednie nie jest opatrzona numeracją arabską i nie została nagrana. Utrzymana jest w zbliżonej nowoczesnej harmonii i nietypowej obsadzie obejmującej: flet piccolo, 3 klarnety $(C), 4$ rogi $(F)$, trąbkę, harfę, ksylofon, tamburyn s.c. i kwintet smyczkowy. Graficzny zapis metrorytmiki ogranicza się do podania obowiązującej liczby miar w taktach zaznaczonych przerywanymi kreskami (6」 w t. I, 4d w t. 2-7) i czasu trwania - I5".

Podstawę kompozycji tworzy pulsująca stale płaszczyzna dźwiękowa złożona z repetowanych - w naprzemiennej formule wymiany ósemek - dwóch współbrzmień: w rogach (kwartowo-sekundowe) i klarnetach (kwartowe), wzmocnionych równym pulsem tamburyna. Na jej tle pojawiają się punktowe dźwięki swobodnie nawiązujące do skali pentatonicznej (hemitonicznej) w ksylofonie i trąbce, następnie zaś ósemkowe motywy tercjowo-sekundowe, wzbogacone partią fletu piccolo o nieregularnej akcentacji i zakończone nagłym pionem tutti sforzato.

Forma poprzez zastosowanie repetytywnego niby basso continuo nasuwa skojarzenie z ciagłym, mechanicznym alarmem. Pulsujący sygnał najpierw lapidarnie nabrzmiewa, wplatając pojedyncze dźwięki i incydentalny synkopowy motyw (t. 4) rytmiczne nawiązanie do historycznie usankcjonowanego wyznacznika formy sygnałowej. Następnie meandrująco-wznosząca się atonalna melika, utrzymana w dynamice crescendowej, wzmacnia napięcie poplątanego dramatyzmu zamkniętego nagłym sforzato. Brzmieniowy charakter utworu w połączeniu z nietypową obsadą i fakturą stwarza wrażenie parodii bądź groteski. Sytuuje utwór pomiędzy dwoma wcześniejszymi („,sonorystycznymi”) i kolejnymi („,klasycyzującymi”). Partytura opatrzona jest dopiskiem „Dla Telewizji”, sugerującym przeznaczenie i funkcję kompozycji.

Wersja III „dla wsi” [symbol 6]

Ostatnim przykładem wśród nienagranych propozycji, który jednocześnie został opatrzony cyfrą 6, świadczącą o kwalifikacji do realizacji nagrania, jest określona przez autora jako Wersja III. Utwór jest jedyną kompozycją Maksymiuka w metrum trójmiarowym, wyraźnie różną od wersji I-IV. Ma formę stylizacji na uroczysty taniec w tona- 
cji Es-dur, w tradycyjnej fakturze (układy tercjowe akordów) i obsadzie symfonicznej ${ }^{58}$. Zapisany - jak kolejne wersje - w konwencjonalnej formie taktowej99.

Dwutaktowa introdukcja ( $\mathrm{w}$ dominancie tonacji) - z charakterystycznym kwintowym zawołaniem w rogach (synkopowo-ósemkowy motyw podjęty dwukrotnie) inicjuje prezentację polonezowej melodii $\mathrm{w}$ instrumentach dętych drewnianych, wspomaganych tutti orkiestry realizującej harmonię. Kształt melodii nosi znamiona regularności, wykazując klarowną symetrię i podział na dwie części: pierwszą (t. 3-6) z motywem polonezowym (ukazanym $\mathrm{w}$ tonice, następnie $\mathrm{w}$ subdominancie) oraz odcinek o zagęszczonym rytmie do przebiegów ósemkowych (z synkopa na raz, wyszczególniony przez Karola Hławiczkę jako wokalny rytm polonezowy $\left.{ }^{60}\right)$, operujący odniesieniem dominantowo-tonicznym podjętym w progresji i zakończony na dominancie tonacji, podkreślonej w partii perkusji (timp., piatto) długo wybrzmiewająca wartością na drugą miarę taktu.

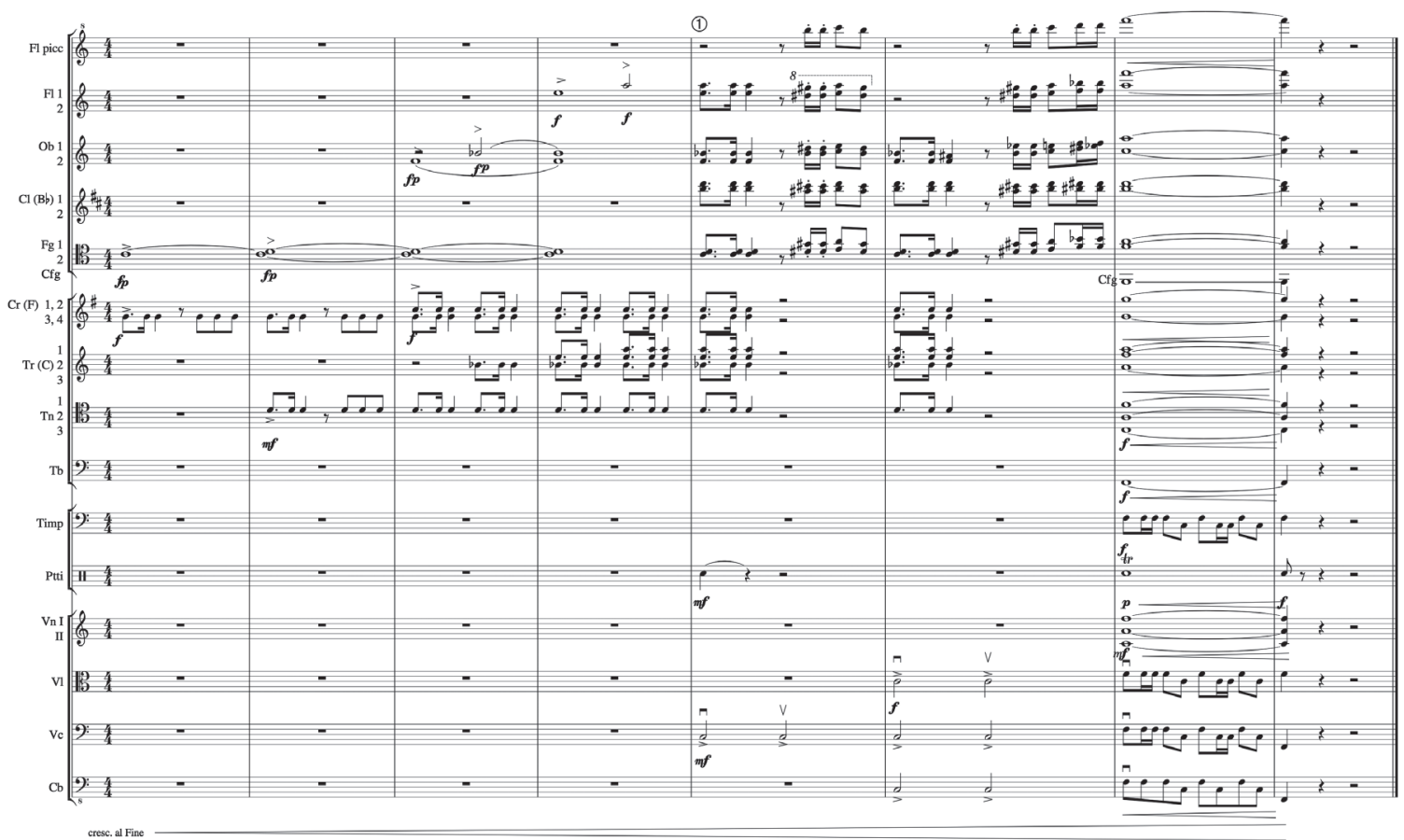

Przykł. 3. Propozycja Sygnatu do Kroniki Jerzego Maksymiuka, Wersja III (1967). Opr. własne na podstawie materiałów archiwalnych WFDiF.

58 Fl. picc, 2, Ob., 2 Cl. (B), Fg., Cfg., 4 Cor. (F), 3 Tr. (C), 3 Tmb., 1 Tb., Timp., Ptti, Ar., I Vn., II Vn., Vle, Vc., Cb.

59 Metrum oznaczone przez wyszczególnienie podstawowych miar w takcie.

6o Por.: E. Dahlig-Turek, op. cit., s. 48. 
Tradycyjna szata harmoniczna, taneczna motywika, sielankowo-pastoralny, a zarazem uroczysty charakter sytuuje tę wersję na skrajnym biegunie względem trzech opisanych wyżej wersji $(I, I I, I V)$. Symptomatyczne jest, poza wspomnianą już intonacją rogu nawiązującą do toposu polowania ${ }^{61}$, wykorzystanie motywiki polonezowej (obecnej także w sygnale Władysława Szpilmana). Forma Wersji III wykazuje jednak w konfrontacji z oryginalną kompozycją Szpilmana zupełnie inaczej ukierunkowany dynamizm (poprzednikowo-następnikowy), zauważalny jedynie w końcowych, schematycznie spiętrzonych, triumfalistycznych taktach poprzez podniesienie energii w progresywnej repetycji synkopowanego motywu.

Zastosowanie dominanty na otwarcie i zakończenie oraz autorski dopisek „dla wsi” ${ }^{62}$ sugeruje, iż Wersja III pisana była z myślą o specyficznej formule jej zastosowania (być może dla wybranego dodatku do Kroniki przeznaczonego dla wsi, ewentualnie przy materiale o specjalnej tematyce, bądź w wewnętrznych częściach Kroniki).

\section{Podsumowanie nowych projektów konkursowych z roku 1967}

Każda z omówionych nowych propozycji Sygnatu PKF w indywidualny sposób nawiązuje do wybranych elementów form sygnałowo-fanfarowych, z pewnym dystansem traktując spójność z ideowymi założeniami tego wyjątkowego gatunku kronikarskiego. Kompozycja Wojciecha Kilara wydaje się podkreślać cechę określaną mianem vaunting - chwalebno-uroczystej, która w pierwotnym znaczeniu wyróżniała fanfary spośród militarnych gatunków sygnałowych ${ }^{63}$, wyjątkową także poprzez swoiste połączenie cech archaizująco-modalizujących i neoklasycznych. Kompozycja Henryka Mikołaja Góreckiego w konsekwentnej formule dążenia do rozbudowania kwartowego brzmienia i rozwiązania kumulowanego napięcia w końcowej tonice tonacji $C$-dur konotuje fanfarowy idiom witalistycznego triumfu w nowej szacie brzmieniowej. Wersje Jerzego Maksymiuka prezentują cały szereg różnych formalnych rozwiązań i konotacji sygnałowych. Trzy pierwsze (I, II, IV) nienagrane, są wyraźnie nowoczesnymi kompozycjami, utrzymanymi we współczesnej fakturze, przywodzące na myśl koncepcje dźwiękowe dla dynamicznych, intensywnych w wyrazie kadrów filmowych, łączącymi fakturę sonorystyczną i punktualistyczną. Wersja nr IV ma wyraźnie wyznaczony krąg tonalny (ostinato współbrzmień kwartowych z quasi-tonalnym ornamentem melodycznym), I i II są zaś zogniskowane wokół ruchomych centrów tonalnych wyznaczonych klasterami. Ich ostra brzmieniowość stanowi intrygującą cechę, przełamującą dominujący w pozostałych kompozycjach standardowy element wybrzmiewającej pozytywnie wiktorii. Trzecia wersja Sygnatu jest jedyną stylizacją utrzymaną w metrum trójmiarowym z wykorzystaniem ryt-

6I Por.: Raymond Monelle, The musical topic: Hunt, military and pastoral, Bloomington-Indianapolis 2006.

62 Adnotacja słabo czytelna.

63 Por.: E.H. Tarr, op. cit. 
micznych wzorów poloneza; jej pastoralny charakter i narracyjne przeprowadzenie stanowi także opozycyjną cechę względem dynamizmu i koncepcji przeprowadzenia formy w introdukcji Szpilmana. Kolejne wersje ( $V, V I, V I I$ i $V I I I)$ wykazują cechy formy tanecznych jak marsz i gigue, zachowują jednak odrębną, sygnałowo-aforystyczną stylistykę. Noszą znamiona kompozycji eklektycznych poprzez połączenie klasycznych (także modalnych) i wychodzących poza krąg odniesień tercjowych współbrzmień harmonicznych. Obecna we wszystkich motywika sygnałowa wyznacza konsekwentną budowę formy, zwykle symetryczną, podążającą za kinetyką harmonii. Orkiestracja w przeważającej mierze obejmuje niemal pełen symfoniczny zespół, z wyjątkiem aranżacji przeznaczonej wyłącznie na instrumenty dęte blaszane (z towarzyszeniem perkusji). Najmniej konwencjonalną ze względu na obsadę jest Wersja nr IV, która wraz z dwoma pierwszymi - prawdopodobnie ze względu na ich nietradycyjną fakturę - nie została zakwalifikowana do nagrania.

\section{WNIOSKI}

Sygnat PKF autorstwa Władysława Szpilmana nagrano trzykrotnie: w roku I95I, I967 i I970. W Kronice funkcjonowały jedynie dwa nagrania (z I95I i I970 r.). Jedyny stereofoniczny zapis z 1967 r. nie został wprowadzony do użytku, podobnie jak towarzyszące mu na źródłowej taśmie wersje nowych, nieznanych propozycji sygnałowych, sporządzonych przez Kilara, Góreckiego i Maksymiuka. Choć dane na temat realizacji nagrania, szczegółów inspiracji organizacji całej inicjatywy oraz kontekstu decyzyjnego i wykonawczego są skąpe, zarówno źródła (partytury i nagrania zgromadzone w WFDiF), jak i okoliczności polityczne okresu, w którym dochodzi do zamówienia (obfitujące w antysemickie gesty władz ${ }^{64}$ ), wskazywać mogą na odgórne zalecenie przeprowadzenia szerokiego przedsięwzięcia rewaloryzującego dotychczasowy sygnał ${ }^{65}$. Zrealizowano je w sposób niepomijający pierwotnej kompozycji, lecz włączający do-

64 Jak zauważa Krystyna Kernstern, w tym okresie oficjalna propaganda nie tylko lansowała wśród społeczeństwa populistyczne slogany przesycone antysemickimi podtekstami, ale i łączyła je z działaniami skierowanymi przeciwko środowiskom inteligenckim, które sprzyjały procesom demokratyzacyjnym, por.: Krystyna Kersten, Polacy, Żydzi, komunizm: anatomia pótprawd 1939-1968, Warszawa 1992, s.166.

65 Wojciech Trębacz wskazuje na incydent wykluczenia Władysława Szpilmana z oficjalnych środków przekazu (m.in. w dwudziestą rocznicę „wydarzeń marcowych”) po tym, jak w związku z wojną arabsko-izraelską aparat bezpieczeństwa odnotował (w donosach jednego z informatorów SB z czerwca) wypowiedzi „proizraelskie” kompozytora. Stały się one pretekstem do „rozpracowania” muzyka za „wrogą działalność”, zob.: Wojciech Trębacz, „Pianista pod specnadzorem”, Biuletyn Instytutu Pamięci Narodowej 5 (2005) nr 11, s. 58-60. Na pilne odnotowanie w materiałach MSW wszelkich sympatii pod adresem armii izraelskiej wskazuje także Jerzy Eisler, Polski rok 1968, publikacja IPN on-line, https://pamiec.pl/pa/biblioteka-cyfrowa/publikacje/10191,Jerzy-Eisler-Polski-rok-1968.html, s. 469. Z kolei Mirosław Biełaszko, analizując sytuację środowiska muzycznego będącego pod kontrolą kilku departamentów MSW, zwraca uwagę na fakt, że Szpilman był nadzorowany przez aparat bezpieczeństwa także i w okresie poprzedzającym wojnę sześciodniową, między innymi w związku z działalnością i licznymi wyjazdami Kwartetu Warszawskiego, którego był stałym członkiem i współzałożycielem, por.: Mirosław Biełaszko, „Fałszywe nuty: próby infiltracji środowiska muzycznego w PRL”, Rzeczpospolita 27 (2008) nr 208, dod. Artyści w pętli PRL, s. 8. 
tychczasową wersję do „klasyfikacji konkursowej”. Jednocześnie zaangażowani zostali jednak nowi twórcy odnoszący sukcesy międzynarodowe (Refren Góreckiego w tym samym roku zostaje nagrodzony przez Międzynarodową Trybunę Kompozytorów) i odnajdujący się świetnie także w materii sztuki filmowej (Kilar od blisko dekady pisze muzykę filmową, a Maksymiuk właśnie zrealizował kilka zamówień dla WFDiF). Przedstawione do konkursu projekty łączy kilka elementów stanowiących zapewne warunki zamówienia: zbliżony czas trwania (ok. Is sekund), forma obejmująca dwie homologiczne części - introdukcję i finał (Sygnat początkowy i Zakończenie), ujęcie w kilku alternatywnych wersjach tonalnych lub instrumentalnych. Cechuje je zróżnicowany profil dynamizmu, odmienna intensywność nawiązań stylistycznych i inaczej podjęte uszeregowanie gatunkowych elementów formy. Propozycje nowych kompozycji ukazują zróżnicowane wyrazowo alternatywy dla dotychczasowego wywoławczego sygnału Kroniki autorstwa Władysława Szpilmana. Obecna jest w nich symptomatyczna dla gatunków sygnałowych cecha - apelatywno-introdukcyjny potencjał - lecz nawiązanie do ideowego charakteru samej Kroniki (niełatwego w syntetycznym ujęciu) wydaje się w tych nowych kompozycjach (być może celowo) odległe.

Autorzy zgłoszonych w 1967 r. opraw dźwiękowych formalnie zaproponowali po kilka wersji sygnału, choć ich różne odsłony - poza wyjątkowo zróżnicowaną stylistycznie grupą autorstwa Jerzego Maksymiuka - najczęściej dotyczą wariantowania wersji podstawowej (wariant instrumentacji bądź tonacji). Konkurs nosi znamiona kilkuetapowej kwalifikacji, jako że realizacja akustyczna sygnału i jego wersji przeznaczonej na zakończenie Kroniki objęła tylko wybrane kompozycje spośród zgłoszonych propozycji. Nie zdecydowano się nagrać nowoczesnych koncepcji Maksymiuka, ani stylizacji polonezowej jego autorstwa, odrzucając zarówno zbyt ostre (ironiczne?) kontrasty, jak i zbyt jaskrawe (i jednocześnie zbyt proste) nawiązanie. Frapująca pozostaje kolejność nagrań w 1967 r.; pozostaje zagadką, czy układ utworów na taśmie łączył się z hierarchią konkursową ${ }^{66}$, czy miał inne, być może pragmatyczne, przyczyny. Warto podkreślić pionierską próbę akustycznie nowej realizacji nagrania sygnałów wykazującej drobne niedomagania wykonawcze czy techniczne.

Wybór i zestawienie nowych kompozycji z legendarnym sygnałem zdają się uwypuklać jego znamienną formę, łączącą kilka cech decydujących o wyjątkowej nośności introdukcji i jednocześnie spójności z pierwotną koncepcją magazynu: rytmiki typowej dla polskiej tradycji, elementów hejnałowo-sygnałowej melodyki i żywioło-

66 Jako pierwszą nagrano kompozycję Wojciecha Kilara o konotacjach uroczystej pieśni (religijnej), następnie witalistyczny sygnał Henryka Mikołaja Góreckiego i pierwotny autorstwa Władysława Szpilmana. Kolejne cztery wersje Jerzego Maksymiuka zdają się być uszeregowane zgodnie z intensywnością nawiązań do form fanfarowo-sygnałowych (lecz z pominięciem polonezowej wersji opatrzonej jednak kwalifikacyjnym numerem 6). 
wej energii fanfary ${ }^{67}$. Czy był to argument przemawiający za brakiem zmiany i decydujący o pozostawieniu dotychczasowego sygnału PKF? Jak potoczyły się wobec tego losy pozostałych kompozycji?

Propozycje nowych wersji sygnału PKF - w przeciwieństwie do nowej oprawy graficznej - nie znalazły zastosowania jako introdukcje magazynu nawet na krótką próbę. Ich zapomniana brzmieniowość czeka więc na odtworzenie ${ }^{68}$, bo choć podjęta decyzja o braku zmiany słynnej dźwiękowej oprawy czołówki Kroniki wydaje się słuszna, to zasługują one na odnotowanie. Dają świadectwo podjęcia nowych prób realizacji nagrań i innych egzemplifikacji sygnałowych, które - mimo swej miniaturowej skali - w pewnym sensie utrwalają także cechy rozpoznawalnych stylistyk ich twórców. Stanowią także ważny ślad historii Polskiej Kroniki Filmowej w roku 1967 i zapoznanych przemian wokół dźwiękowego oblicza czołówki autorstwa Władysława Szpilmana.

\section{THE POLISH FILM CHRONICLE SIGNATURE TUNE}

\section{AND ITS UNKNOWN VERSIONS OF I967}

Polska Kronika Filmowa (The Polish Film Chronicle, PKF) opened in its early years (1945-5I) with a bombastic music motif, a form of quotation. From 1952 onward, the title sequence was accompanied by a music piece specially composed by Władysław Szpilman, which was broadcast without any changes until 1994 and became the trademark of this newsreel, as well as a soundmark of the Polish audiosphere. One of its distinguishing features were its polonaise rhythms. The ionicus a minore formula, correlated with dynamic progressions (including modulations and remodulations) and a bugle-call-like melody - made this tune highly popular and recognisable. Sources found in the WFDiF (Warsaw Documentary Film Studio) prove, however, that alternative versions of the PKF signature tune were composed in 1967. These unpublished compositions by H.M. Górecki, W. Kilar and J. Maksymiuk were

67 Warto przypomnieć, że w polskim pejzażu dźwiękowym początku XXI w. wśród wielu dźwiękowych emblematów stosowanych $\mathrm{w}$ mediach $\mathrm{w}$ funkcji sygnału (i stanowiących zgodnie $\mathrm{z}$ terminologią R. Murraya Schafera swoisty dla regionu soundmark audiosfery) niejednokrotnie wykorzystywano pieśni o charakterze patriotycznym (Mazurek Dąbrowskiego, Warszawiankę, Pieśń Legionów), pieśni religijne (Kiedy ranne wstaja zorze) oraz lokalne pieśni ludowe bądź utwory o randze narodowego symbolu jak Polonez A-dur op. $40 \mathrm{nr}$ I F. Chopina. W początkach działalności polskiej radiofonii i kinematografii częstym i emblematycznym motywem staje się polonezowa formuła, w szczególności zaś początkowe takty wspomnianego wyżej Chopinowskiego poloneza. To one stają się sygnaturą rozgłośni Polskiego Radia, a w orkiestralnej transkrypcji chopinowski motyw towarzyszy emisjom Polskiej Kroniki PAT poprzedniczki Polskiej Kroniki Filmowej. Podobną reprezentacyjno-rozpoznawczą funkcję, konotującą w sposób symboliczny elementy polskiej rytmiki, pełnił Sygnat Władysława Szpilmana zapowiadający do ostatnich wydań z 1994 r. Polską Kronikę Filmową. Szczegółowe porównanie m.in. motywu polonezowego w kontekście Sygnatu PKF zaproponował w swojej analizie Maciej Gołąb (op. cit., s. 278-293).

68 Zamierzeniem autorki jest wydanie wybranych kompozycji w formie audialnej, jako dopełnienie artykułu i pracy na temat twórczości kompozytorskiej Władysława Szpilmana. 
recorded along with Szpilman's piece in two versions, one opening and the other - closing the newsreel. Each of the new proposed tunes is about I5 seconds long and, in most cases, scored for a symphony orchestra. W. Kilar's piece resembles a solemn song, which combines extended tonality with neo-Classical elements. It has versions in several different keys (similarly to W. Szpilman's original tune, written out in B-flat major and C major). H.M. Górecki's piece is characterised by a broad sound and a repeated rhythmic motif. It fuses fourth harmonies with the euphonic colours of a vitalistic close. Both composers' tunes were recorded in versions with and without string quintet. J. Maksymiuk presented the largest number of proposals (versions I-VIII), varying in texture and style. The first four (three contemporary-style, and one polonaise stylisation) were left unrecorded, while the others (for orchestra or brass ensemble with percussion) represent various uses of march-like and dance elements.

The recording of 1967 remains anonymous. Audio analysis shows that it was made in a large hall, in stereo. We do not know who inspired this project, but most likely it was associated with attempts to change the PKF title sequence (including the graphics) and with political interventions. Eventually, however, the legendary piece by W. Szpilman remained intact as the Chronicle's signature tune.

Translated by Tomasz Zymer

Słowa kluczowe / keywords: Polska Kronika Filmowa / the Polish Film Chronicle, Władysław Szpilman, Henryk Mikołaj Górecki, Jerzy Maksymiuk, sygnał dźwiękowy / soundmark

Kamila Staśko-Mazur, obecnie przygotowuje pracę doktorską na temat twórczości kompozytorskiej Władysława Szpilmana. Współtworzy zespół Pracowni Badań Pejzażu Dźwiękowego (przy Instytucie Kulturoznawstwa Uniwersytetu Wrocławskiego), prowadzi działalność edukacyjną m.in. w ramach Podyplomowych Studiów „Dźwięk i audiosfera” (przy Instytucie Muzykologii Uniwersytetu Wrocławskiego). Autorka projektów i realizacji artystycznych o profilu ekologii dźwiękowej (CSW, NFM, CSD, A-I-R, SoCCos, GMVL, ULL2).

e-mail: kamila.staskomazur@gmail.com

\title{
Nowa seria wydawnicza Instytutu Sztuki PAN „Muzyka polska za granica”
}

\author{
Tom 1: Twórcy - źródła - archiwa \\ red. Beata Bolestawska-Lewandowska i Jolanta Guay-Pasiak
}

iswydawnictwo@ispan.pl 
